Publicación semestral. ISSN 2215-4906

Volumen 80 - Número 2

Enero - Junio 2021

\title{
Museo de la Dignidad: entre la polémica y la memoria. Una mirada sobre las acciones artístico-políticas en el octubre chileno de 2019
}

\author{
Museum of Dignity: between Controversy and Memory.
}

A look at the Artistic-Political Actions in the Chilean October of 2019

Raíza Ribeiro Cavalcanti

Teresa Maria Barbosa de Oliveira

\section{(c) (i) $($ )}

Esta obra está bajo una licencia Creative Commons

Reconocimiento-No comercial-Sin Obra Derivada 


\title{
Museo de la Dignidad: entre la polémica y la memoria. Una mirada sobre las acciones artístico-políticas en el octubre chileno de 2019
}

\author{
Museum of Dignity: between Controversy and Memory. \\ A look at the Artistic-Political Actions in the Chilean October of 2019
}

\author{
Raíza Ribeiro Cavalcanti ${ }^{1}$ \\ Universidad de Chile \\ Chile \\ Teresa Maria Barbosa de Oliveira ${ }^{2}$ \\ Superintendência de Desenvolvimento do Nordeste
}

Brasil

Recibido: 02 de junio de 2020 Aprobado: 14 de octubre de 2020

\begin{abstract}
Resumen
La revuelta social del 18 de octubre, en Chile, constituyó un proceso que estremeció al país desde sus bases más profundas. Ese momento de explosión social estuvo acompañado de una igual explosión en la producción de imágenes, performances y acciones artísticas, por todo el país, que evidenciaron la profunda dimensión simbólica de las manifestaciones. En ese contexto, llama la atención la acción Museo de la Dignidad, creada por un colectivo homónimo, que interviene en las imágenes producidas por las protestas, dispuestas en los muros de la ciudad de Santiago. Estas intervenciones insertan acciones callejeras en marcos dorados y suscitan una serie de cuestionamientos importantes sobre el arte y las instituciones de la cultura, patrimonio y preservación. Este artículo pretende analizar los distintos efectos de la acción Museo de la Dignidad en la esfera pública, a partir

${ }^{1}$ Coordinadora General del Laboratorio Museos y Museologías en el Chile Contemporáneo - LAB Museos de la Universidad de Chile. Doctora en Sociología. ORCID: 0000-0002-7679-405X. Correo electrónico: raiza.ribeiro@uchile.cl

2 Analista técnica administrativa en la Superintendência de Desenvolvimento do Nordeste (SUDENE). Máster en Sociología. ORCID: 0000-0003-0097-4836. Correo electrónico: tersanajanela@gmail.com
\end{abstract}


del método del Análisis de Discurso Crítico (Fairclough, 2001). Se enfatizará el aspecto de práctica discursiva crítica que interfiere en la esfera pública (tanto artística como socialmente), lo cual produce el disenso (Mouffe, 2014; Rancière, 2009) y baraja los regímenes del arte (Rancière, 2005) en su presencia.

Palabras clave: artes gráficas; arte y política; arte contemporáneo; instituciones culturales; revuelta social

\begin{abstract}
The social revolt of October 18, in Chile, became a process that shook the country from its deepest foundations. This moment of social explosion was accompanied by an equal explosion of the production of images, performances and artistic actions throughout the country, highlighting the deep symbolic dimension of the protests. In this context, the "Museum of Dignity" action, created by a group of the same name, calls attention. It intervenes in the images produced by the protests, arranged on the walls of the city of Santiago. The interventions produced by the Museum of Dignity group, which insert street actions into golden frames, raise a series of important questions about art, institutions of culture, heritage and preservation. This article tries to analyze the different effects of the Museum of Dignity action in the public sphere, based on the method of Critical Analysis of the Discourse (Fairclough, 2001). The emphasis will be placed on the aspect of critical discursive practice that interferes in the public sphere (both artistically and socially) producing dissent (Mouffe, 2014; Rancière, 2009) and shuffling the regimes of art (Rancière, 2005) in their presence.
\end{abstract}

Key words: grafic arts; art and politics; contemporary art; cultural institutions; social revolt 
Museo de la Dignidad: entre la polémica y la memoria.Una mirada

Dossier sobre las acciones artístico-políticas en el octubre chileno de 2019

\section{Introducción}

El actual proceso de revuelta social que se vive en Chile desde el 18 de octubre de 2019 ha estremecido al país desde sus bases más profundas. Tal como los movimientos telúricos, tan comunes en esta región del mundo, el llamado estallido social ha producido un movimiento radical de transformación, cuyas repercusiones son aún desconocidas en su magnitud y profundidad, pero visiblemente de una potencia sin precedentes. Dichos efectos han tenido una especial expresión en la producción de imágenes, performances y acciones simbólicas que confrontan los imaginarios nacionales, las narrativas coloniales, las construcciones históricas y patrimoniales y sus instituciones. La explosión gráfica y performática en Chile tras el estallido, a pesar de no ser una novedad en la producción artístico-política del país (las brigadas muralistas y las producciones gráficas de los años 1960 a 1980 son algunos ejemplos históricos), posee un componente performativo importante que se diferencia de las expresiones gráficas anteriores: el profundo cuestionamiento de la epistemología moderna que funda el mismo Estado neoliberal chileno y sus instituciones (crítica que se relaciona con el cuestionamiento global de los presupuestos del modelo democrático y de gestión pública neoliberal que destruyó el estado de bienestar).

En el marco de esa explosión imagético-artística, este artículo propone analizar la acción Museo de la Dignidad, creada por un colectivo homónimo, que interviene en la ciudad a partir de las imágenes producidas por el estallido social. La estrategia del grupo se basa en la elección aleatoria de imágenes presentes en los muros de Santiago sobre las cuales se insertan molduras doradas, simulando la puesta en escena neoclásica de las bellas artes. Este juego dicotómico entre el neoclasicismo decimonónico evidente en los marcos dorados -que evoca al arte atemporal, eterno y aurático, en contraste con las imágenes callejeras y su condición efímera- ha provocado debates. La acción ha producido cuestionamientos acerca de su legitimidad (¿quiénes son y cuáles criterios utilizan para elegir los trabajos enmarcados?), su intencionalidad (¿qué esperan con eso? ¿cuál es la importancia o necesidad de enmarcar y reinsertar el arte callejero en la lógica institucional?) y su efectividad (¿qué lograrán con eso? ¿cómo esperan eternizar esas imágenes efímeras?).

Pretendemos analizar esta acción en el marco de su presencia performática en las calles de la ciudad de Santiago y en la esfera pública virtual, además de profundizar el debate sobre los sentidos que ponen en movimiento. Para lograrlo, comprenderemos el Museo de la Dignidad como una acción de arte contemporáneo que moviliza distintos signos y sentidos relacionados con las artes visuales, confrontándolos en ese lugar de exterioridad institu- 
cional que es la calle. Para lograr el análisis del trabajo, el artículo utilizará una metodología de colecta de imágenes (in situ y digitales) sobre la acción en distintos períodos de tiempo, para medir el efecto producido por la calle y sus movimientos en las imágenes. El corpus del artículo incluye, también, la colecta de comentarios publicados por usuarios de redes sociales y artículos online, como medio para mensurar su impacto en la esfera pública local (al considerar que las redes sociales conforman una esfera pública virtual que ejerce importante influencia en la esfera pública real actualmente).

\section{Movimientos políticos en Chile: ¿cómo comprender el octubre de 2019?}

A partir del período de la redemocratización de la sociedad chilena, es posible observar el surgimiento de un conjunto de nuevos movimientos políticos que articulan y lideran los principales conflictos y tensiones que han marcado la relación entre el Estado y la sociedad en este país. Las luchas por la expansión de la ciudadanía y el consiguiente acceso a derechos como la educación, la salud, la seguridad social, la vivienda y la movilidad fueron puntos importantes de estas organizaciones colectivas. En el ámbito de los conflictos laborales, se observan intentos de rearticulación de sindicatos y asociaciones sindicales en diferentes sectores. Asimismo, se destaca de manera muy relevante la emergencia (la visibilidad) de un conjunto de conflictos donde los pueblos originarios y las cuestiones socio ambientales surgen como sujetos.

El proceso de redemocratización generó la expectativa de un país más justo e inclusivo, sin embargo, lo que se observó fue el aplazamiento continuo de este proyecto, sumado a una gran deuda pendiente desde el período militar. Entre las diversas continuidades del período de la dictadura, destacamos la exclusión de las minorías al interior de un sistema binomial y de un modelo de administración neoliberal con resultados de privatización y de desregulación de las actividades comerciales y de las operaciones del capital financiero, además de la adopción de un sistema tributario regresivo que privilegia a los dueños de grandes fortunas. En el campo de la ciudadanía y el trabajo, se implementó el sistema de pensiones con capitalización individual, flexibilidad laboral y precariedad. También, se observa la deficiencia de los servicios educativos y de salud, y la carencia de una legislación ambiental que regule eficazmente las acciones depredadoras de las empresas privadas ( $\mathrm{La}$ Cuadra, 2013).

La ampliación de estos problemas llevó a la agudización de los conflictos derivados de ello, que han sido notorios en los años recientes, particularmente desde el último 
Museo de la Dignidad: entre la polémica y la memoria.Una mirada

Dossier sobre las acciones artístico-políticas en el octubre chileno de 2019

gobierno del presidente Sebastián Piñera (quien asumió el cargo en 2018). Junto a estas expresiones de descontento y a la saturación de las frustraciones que se han acumulado durante mucho tiempo, se incluye también una crisis de legitimidad en los sistemas políticos del partido, en las clases políticas y en el propio régimen democrático representativo.

En este sentido, el 2019 se convirtió en un marco para la confluencia de actores organizados políticamente en movimientos sociales instituidos de manera tradicional, de una masa de personas indignadas frente a procesos continuos de empobrecimiento de la vida y de las frustraciones experimentadas en los ámbitos de lo privado y lo individual. En resumen, la masiva revuelta social ocurrida el 18 de octubre de 2019 fue un hito en el movimiento de insurgencia colectiva; desde entonces, se le conoce como estallido social y movimiento por la dignidad. Para comprender todo este proceso, es importante señalar que el estallido de conflictos resulta del profundo cuestionamiento del pacto social que ha organizado las relaciones sociales y económicas entre el Estado y la sociedad durante las últimas tres décadas. Al respecto, Maria Mônckeberk (2019) señala que el conjunto de hechos descritos anteriormente revela el individualismo, la desigualdad y la estratificación social que fueron emergiendo a partir de la "economía de mercado", la cual, actualmente, se define como "modelo neoliberal". Según la autora, son varios los procesos que condujeron al estallido:

aparece el grave deterioro de la educación pública y las continuas protestas de los estudiantes y profesores que lo venían señalando desde hace años; las deudas acumuladas por los créditos y las que se multiplican por los incentivos al consumo de cualquier cosa; las paupérrimas pensiones que entregan las Administradoras de Fondos de Pensiones (AFP) a los que prometieron hace casi cuarenta años jubilaciones fabulosas; los innumerables y agotadores problemas de la salud pública, incluyendo los elevados precios de los medicamentos, y los de las Instituciones de Salud Previsional (Isapres); la falta de viviendas dignas y las ciudades segregadas (Mônckeberk, 2019, p. 75).

De igual manera, Claudio Nash (2019) destaca que lo que Chile vive desde el 18 octubre no es un lamentable e inexplicable factor histórico, "sino que es la consecuencia del proceso de degradación del acuerdo sobre derechos fundamentales en Chile" (pp. 82-83). Las protestas dieron cuenta de las insatisfacciones ciudadanas con un modelo económico que no resguarda los derechos económicos y sociales; evidenciaron los déficits democráticos de espacios de participación real; apuntaron la falta de credibilidad de las instituciones políticas como los partidos y el Parlamento; y develaron el desmantelamiento de las formas asociativas

ESCENA. Revista de las artes, 2021, Vol. 80, Núm. 2 (enero-junio), pp. 253-296 
tradicionales como los sindicatos, colegios profesionales y organizaciones estudiantiles. De ese modo, Maria Monckeberk (2019) destaca que el estallido social no fue por treinta pesos ${ }^{3}$, sino por cerca de cuarenta años, o más, de la dictadura.

\section{"No son 30 pesos": el estallido y las demandas por un nuevo pacto social}

Claudio Lincopi (2019) señala que hay dos pactos sociales que anteceden los conflictos que ahora se presentan: el golpe de 1973 y el del año 1988. Para el autor, guardadas sus diferencias, cada uno de estos acuerdos representa al modelo neoliberal y al de la democracia autoritaria. El golpe militar permitió el asentamiento de un modelo económico de privatización, cuyo "peso y densidad histórica fue la que contaminó el modelo de desarrollo instalado hasta hoy en el país" (Lincopi, 2019, pp. 60-61). Este modelo conocido como El ladrillo fue planificado por un grupo de economistas provenientes de la Universidad Católica, quienes convencieron a los altos oficiales uniformados a aplicarlo. La consecuencia de lo anterior se observa, desde esa época, en procesos como la municipalización de la educación básica y media, cuyo resultado fue que la educación pública decayera a niveles paupérrimos, y la implantación del modelo de la enseñanza particular subvencionada, el cual siguió el mismo esquema de voucher que hasta hoy prevalece también en la educación superior. Al respecto, Maria Mônckeberk (2019) afirma que, a partir de 1981, este plan pasó a ser institucionalizado cuando empezó a regir la Constitución de 1980, creada por el gobierno dictatorial. La nueva carta magna creada en ese momento tenía el objetivo de perpetuar la dominación política y económica instalada por la dictadura. De ese modo, a partir de 1985, los procesos de privatización de las grandes empresas públicas tomaron cada vez más fuerza (Mônckeberk, 2019).

A partir de ahí, se empieza a gestar lo que Claudio Lincopi define como la "democracia de los acuerdos". El autor afirma que el pacto de 1988, fundado en el "plebiscito del Sí y el No", profundizó un modelo democrático hondamente clausurado para los movimientos sociales, donde la participación se resumió al voto, bloqueando cualquier capacidad deliberativa desde los territorios y los pueblos (Lincopi, 2019). El resultado de ello, según Mônckberk, fue la continuidad del modelo económico durante la transición a la democracia

${ }^{3}$ La referencia al valor $\$ 0,30$ (treinta pesos) se relaciona con el alza de precios en el transporte público anunciado por el gobierno de Piñera a finales de septiembre de 2019, la segunda alza de precios del año. El anuncio produjo una serie de protestas espontáneas de estudiantes que fueron duramente reprimidas y que, luego, escalaron hasta generar la explosión masiva del 18 de octubre.

ESCENA. Revista de las artes, 2021, Vol. 80, Núm. 2 (enero-junio), pp.253-296 
Museo de la Dignidad: entre la polémica y la memoria.Una mirada

Dossier sobre las acciones artístico-políticas en el octubre chileno de 2019

durante las décadas siguientes, a partir de los años 1990. Los procesos de privatización de bienes públicos, incluyendo las aguas y los puertos, dejó al país prácticamente sin industrias y limitó la población al trabajo en el sector de servicios, de manera precaria, lo cual resultó en procesos de endeudamiento y empobrecimiento (Mônckberk, 2019).

De ese modo, el 18 de octubre se presenta como un momento de ruptura y cuestionamiento en torno a las estructuras que sostienen todo el pacto social que organiza la forma de vida chilena. Como se ha mencionado, el modelo de desarrollo creado desde la dictadura de 1973, todavía vigente, no pasó por la necesaria revisión y cambio en el momento de construcción del pacto social de 1988. El resultado de eso fue el recrudecimiento de los conflictos producto del déficit en el acceso a los derechos civiles y a la participación social.Además de lo anterior, el estallido social de octubre de 2019 denunció también la naturaleza violenta y militarizada de la respuesta del Estado a los actores políticos organizados y, de ese modo, visibilizó la constante violencia estatal contra los pueblos originales y los estudiantes. En este sentido, el asesinato del comunero mapuche, Camilo Catrillanca, y la tortura de un niño de 15 años que lo acompañaba, en noviembre de 2018, se convirtió en el punto de articulación de la resistencia social de los pueblos tradicionales, de los estudiantes y, como tal, de un conjunto de demandas sociales y de participación que indican la necesidad de revisión del pacto fundacional del país.

Los meses de octubre, noviembre y diciembre de 2019 estuvieron marcados por una amplia gama de protestas callejeras que se iniciaron con la de los estudiantes ante el aumento de pasaje de metro al valor $\$ 0,30$ (treinta pesos). Las manifestaciones se llevaron a cabo por todo el país, pero con mayor énfasis en las calles de Santiago, y sus demandas se extendieron más allá del valor de los pasajes. Las protestas fueron acompañadas por una brutal represión policial y por el uso irrazonable de la fuerza por parte de agentes estatales que ocasionó la muerte de docenas de manifestantes y lesionó gravemente a cientos de otros, en una serie de actos de violaciones de los derechos humanos. El país quedó completamente paralizado por las manifestaciones diarias, hecho que llevó a los principales representantes del Estado, en particular al presidente Sebastián Piñera, a la apertura al diálogo para discutir un nuevo proceso constitucional.

De esta manera, la demanda por cambiar la Constitución -el cuestionamiento de ese compendio articulado y coherente de un modelo de sociedad que fue propuesto, definido y afinado durante la dictadura- se ha transformado en un tema esencial y que ocupa el lugar central para la comprensión del estallido social. Sin embargo, la exigencia es por una participación más directa en el proceso constituyente a partir de organizaciones populares (cabildos, asambleas, coordinadoras, entre otros), lo que le daría al país una salida a un conflicto

ESCENA. Revista de las artes, 2021, Vol. 80, Núm. 2 (enero-junio), pp. 253-296 
de proporciones significativas.

La Asamblea por el Pacto Social destaca que es necesario "encontrar una solución al problema de una clase política que no está escuchando a la ciudadanía y que por lo tanto no representa a nadie" (2019, p. 1). De ese modo, se indica que la insatisfacción con los actuales sistemas de representación se produce por el hecho de que no son capaces de garantizarla. Hay todavía una demanda por espacio en la democracia deliberativa, en la democracia participativa, que es distinta a la representativa, y que propone participación directa, sobre todo a nivel territorial, a través de referéndum, plebiscitos revocatorios, entre otros. En esta misma carta queda evidente la necesidad de revisión del pacto:

Necesitamos una Nueva Constitución. Chile nunca ha contado con una carta fundamental propuesta, conversada, redactada y votada por la sociedad toda. Es el momento de alcanzar un anhelo histórico: que sea el propio pueblo de Chile quien decida los destinos hacia los que quiere avanzar. Nuestra acción continuará hasta lograr una transformación profunda del sistema vigente. Cuestionamos este modelo neoliberal abusivo que convierte nuestros derechos sociales en oportunidades para lucrativos negocios ... A mediano plazo, exigimos una política distinta a la que conocemos. Una política que represente los intereses del pueblo, no el de las empresas. Una política que haga frente a la concentración de la riqueza y las desigualdades. Una política comprometida con la realización de los derechos humanos, civiles, políticos, sociales, sexuales y reproductivos. Una política que se haga cargo de problemas urgentes en áreas como la salud, la previsión, el transporte, la educación, el trabajo y las pensiones, la vivienda, la relación con los pueblos originarios y nuestra realidad plurinacional, el respeto real de los derechos de niños, niñas y adolescentes, la seguridad, el agua, los bienes naturales comunes y el medio ambiente, y en general, el nuevo modelo económico y político que nos daremos como nación. Chile necesita con urgencia un pacto social (Asamblea por el pacto social, 2019, p. 1).

En resumen, se evidenció que la ruptura causada por las manifestaciones callejeras tiene como objetivo reformular los modelos de participación social y las formas de vida. Las demandas y consignas por un nuevo Chile y por una vida con dignidad llevadas a las calles a partir del estallido tomaron especial expresión en la producción de imágenes, performances y acciones simbólicas que confrontan los imaginarios nacionales, las narrativas coloniales, las construcciones históricas (patrimoniales) y sus instituciones. 
Museo de la Dignidad: entre la polémica y la memoria.Una mirada

Dossier sobre las acciones artístico-políticas en el octubre chileno de 2019

\section{Aparición del arte callejero en octubre de 2019}

Una característica que se destacó del actual estallido social chileno fue la producción masiva de imágenes, representaciones y acciones simbólicas que mostró un importante componente performativo de cuestionamiento de la epistemología moderna que funda el mismo Estado neoliberal chileno y sus instituciones (crítica que se relaciona con el cuestionamiento global de los presupuestos del modelo democrático y de gestión pública neoliberal que destruyó el estado de bienestar). Las imágenes dispersas en las calles de Santiago, escenario de las principales manifestaciones en el país, se presentan como una forma de participar y comunicar el fenómeno a partir de una narrativa en la que se pueden observar la profunda indignación y la denuncia del abuso de poder por parte del Estado. A la demanda por la necesidad de participación social en las decisiones políticas del país, especialmente para la construcción del nuevo pacto a través del constituyente popular, le acompañó una inmensa producción visual, ampliando la misma idea de participación.

Los movimientos sociales que se producen en las calles, al mismo tiempo, se narran y reafirman en las paredes de los edificios, para reforzar el evento y lo que se pretende cambiar. Las imágenes de la 1 a la 10 que se muestran a continuación son algunas de las producidas en el mes de noviembre de 2019.
Imagen 1. Afiche y pintura mural que indican rebeldía popular en contra la dominación del gobierno

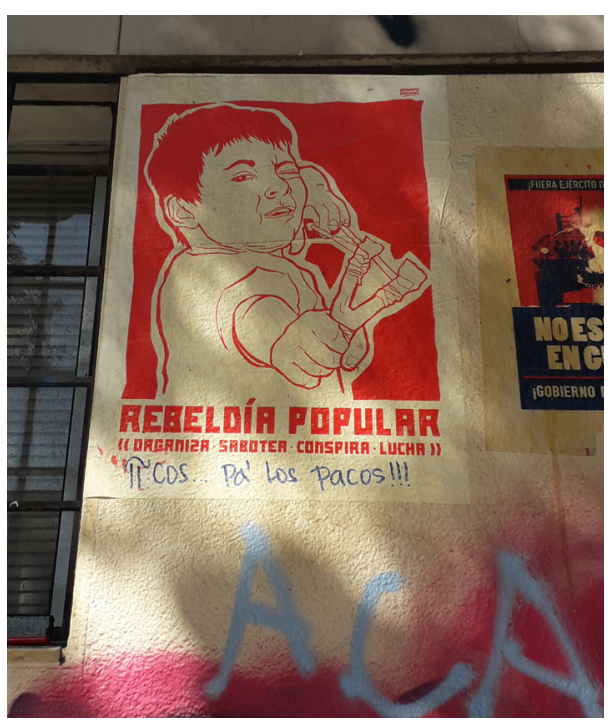

Fuente: Teresa Oliveira (noviembre 2019).

Imagen 2. Afiche y pintura mural que indican rebeldía popular en contra la dominación del gobierno

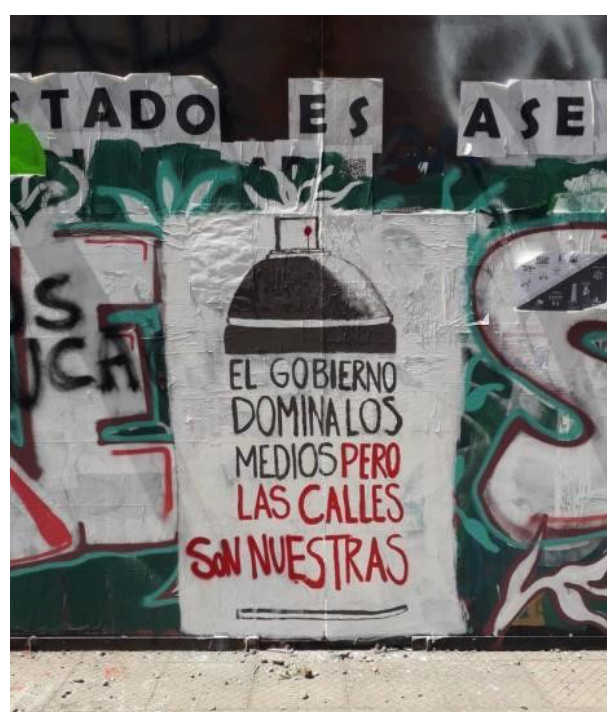

Fuente: Teresa Oliveira (noviembre 2019). 
Imagen 3. Pegatina y stencil que indican decepción del pueblo chileno con el Estado y sus ganas de participación

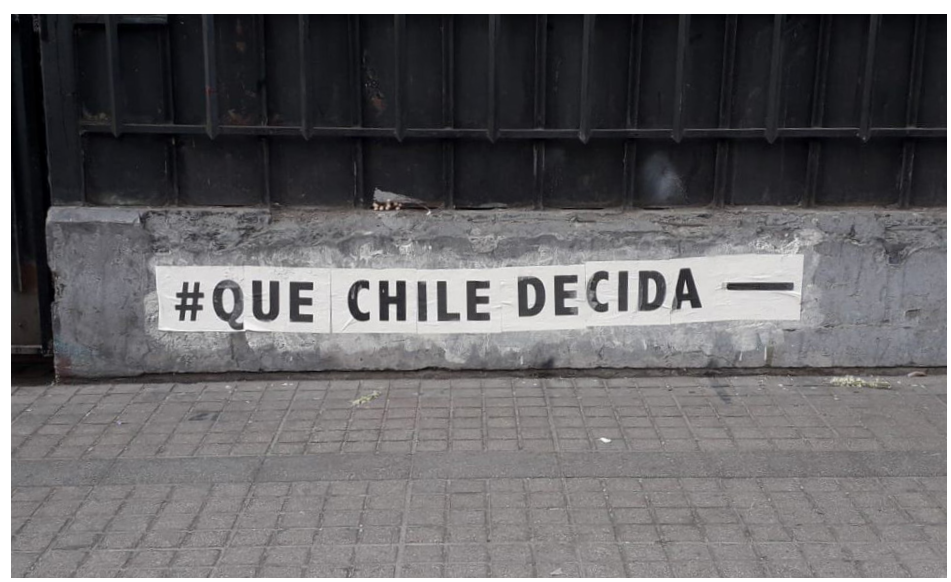

Fuente: Teresa Oliveira (noviembre 2019).

Imagen 5. Cartel del dictador Pinochet a manipular el presidente Sebastián Piñera y Stencil que indica el estado de lucha popular

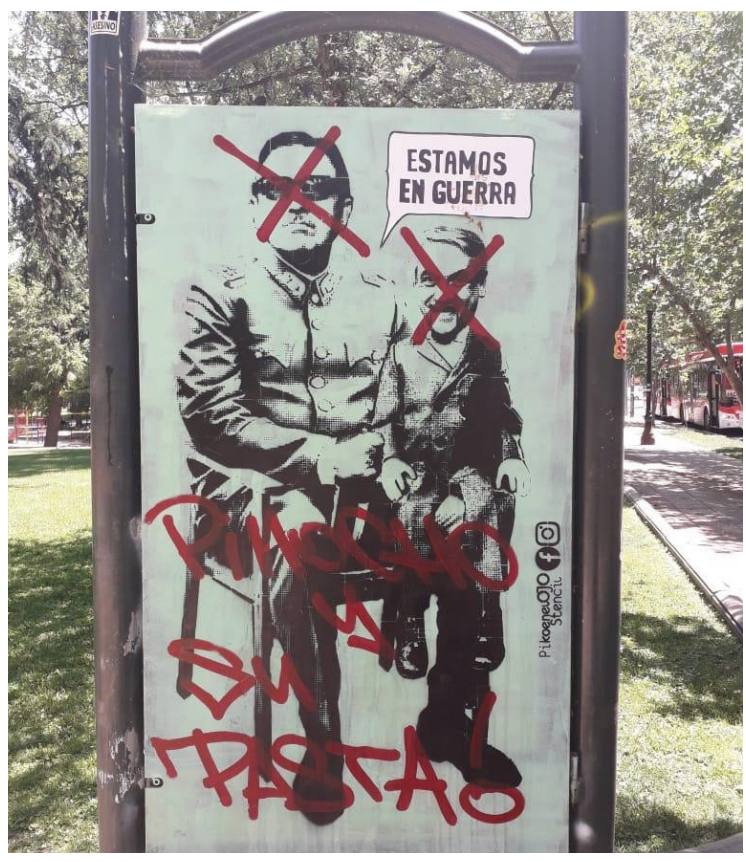

Fuente: Teresa Oliveira (noviembre 2019).
Imagen 4. Pegatina y stencil que indican decepción del pueblo chileno con el Estado y sus ganas de participación

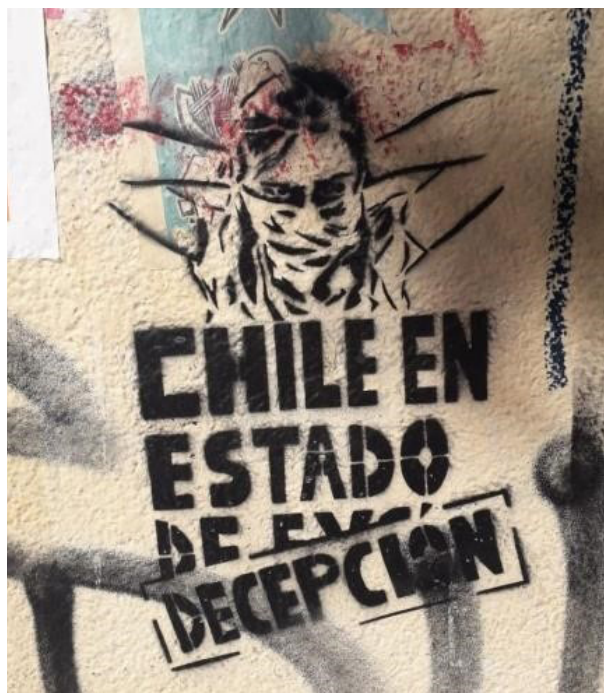

Fuente: Teresa Oliveira (noviembre 2019).

Imagen 6. Cartel del dictador Pinochet a manipular el presidente Sebastián Piñera y stencil que indica el estado de lucha popular

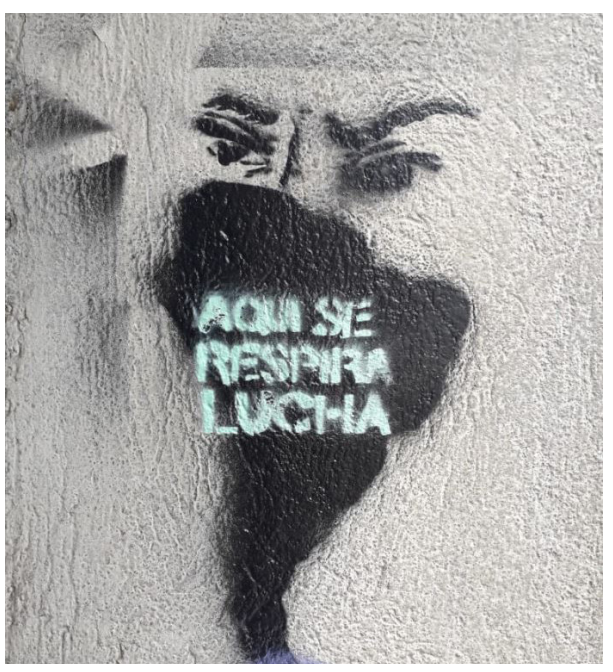

Fuente: Teresa Oliveira (noviembre 2019). 
Museo de la Dignidad: entre la polémica y la memoria.Una mirada

Imagen 7. Grafitis y afiches con críticas al Estado y lucha por la dignidad

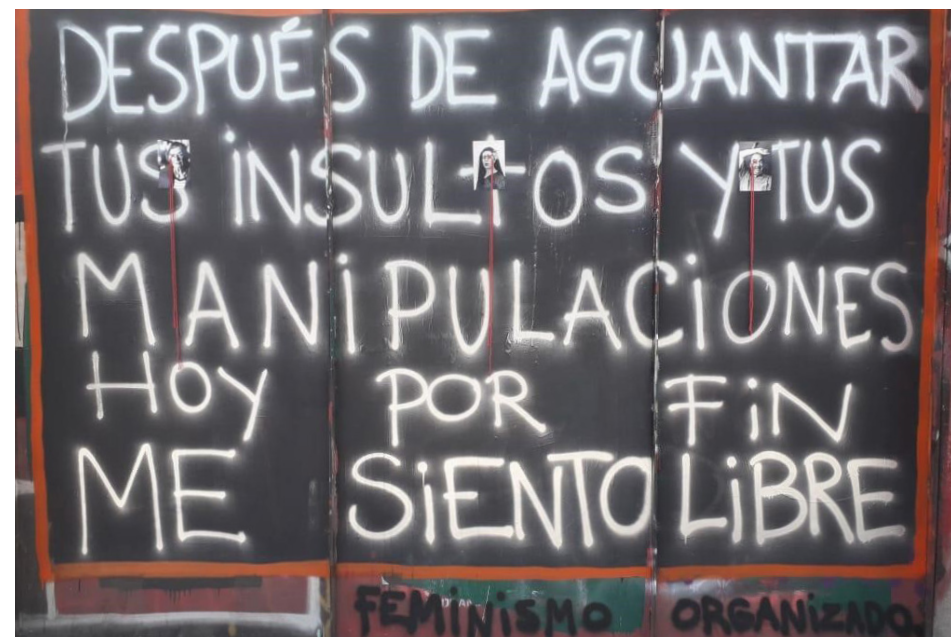

Fuente: Teresa Oliveira (noviembre 2019).

Imagen 9. Carteles en las calles de Santiago

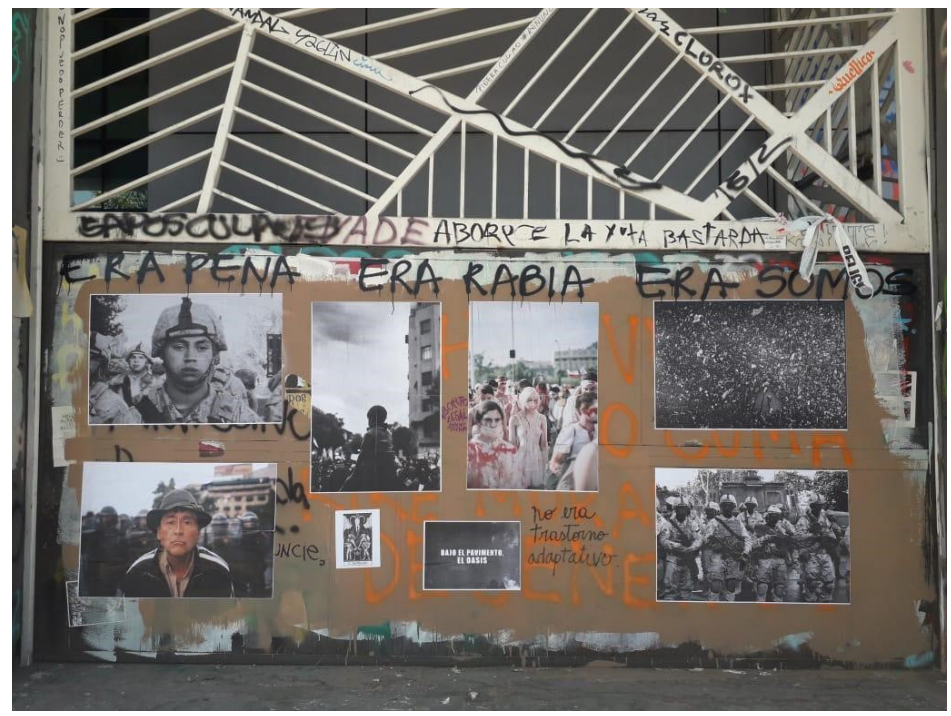

Fuente: Teresa Oliveira (noviembre 2019).
Imagen 8. Grafitis y afiches con críticas al Estado y lucha por la dignidad

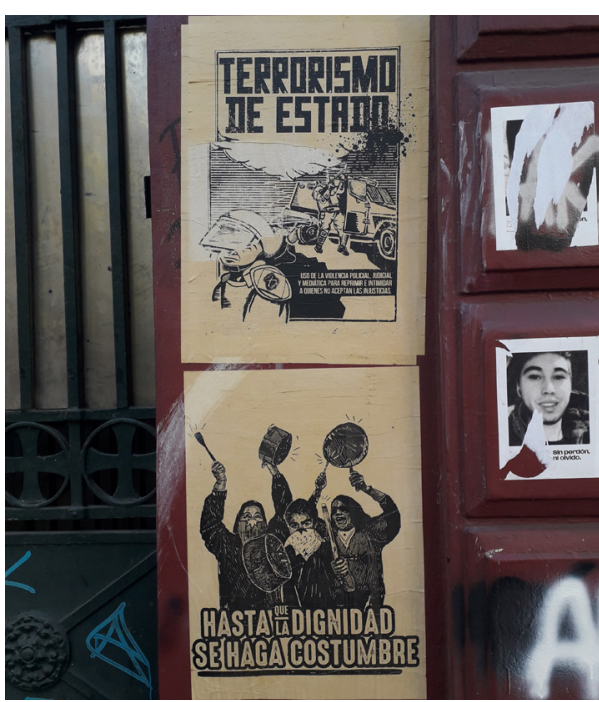

Fuente: Teresa Oliveira (noviembre 2019).

Imagen 10. Carteles en las calles de Santiago

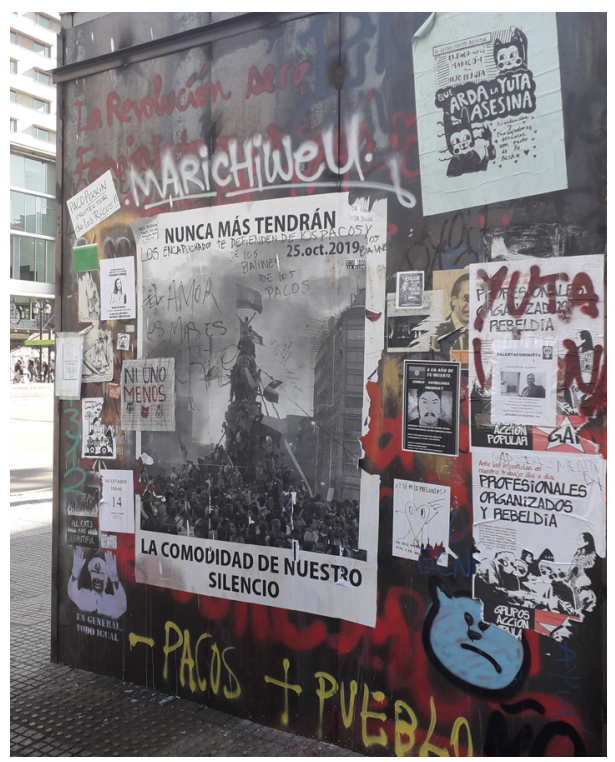

Fuente: Teresa Oliveira (noviembre 2019). 
La actual explosión iconográfica del estallido ha llamado la atención tanto de la ciudadanía como de investigadores con el fin de comprender sus raíces históricas y motivaciones. El investigador Claudio Lincopi (2019), por ejemplo, destaca que, en el actual proceso, existe también un tercer tiempo histórico que las movilizaciones de 2019 han puesto en evidencia y que está presente en la producción del arte callejero: la larga continuidad colonial.

La reivindicación de la wenufoye y la whipala, expresiones simbólicas del pueblo mapuche y los pueblos andinos respectivamente, junto con los hechos de desmonumentalización de figuras icónicas del colonialismo español y republicano, son manifestaciones de un malestar identitario, de una congoja en la configuración de la subjetividad nacional, de una crisis que busca socavar una herida de profundidades centenarias (Lincopi, 2019, p. 61).

El proceso de desmonumentalizar estatuas y parques alrededor de la ciudad produce un efecto de refundación en la narrativa de la construcción del estado chileno. La producción simbólica, por lo tanto, se basa también en un proyecto decolonial que denuncia la lógica opresiva de la violencia imperial y la eliminación de la diversidad étnica que le da origen y apoyo hasta hoy. De ese modo, la Plaza Baquedano se convierte en la Plaza de Dignidad. El Cerro Santa Lucía, hito de la colonización, vuelve a nombrarse Cerro Huelén, como lo llamaban los Mapuche en su idioma Mapudungún. Las estatuas colonizadoras están pintadas y marcadas con las banderas Wiphala de la integración de los pueblos andinos, una expresión de alegría. Hay una infinidad de graffitis y stencils que evocan la memoria y la espiritualidad de los pueblos originales. Hay carteles y pancartas en las calles y en las ventanas de las casas, en las que se afirma la primavera chilena y se reivindica el derecho a ver y respirar, para mantener los sentidos despiertos y apuntar a nuevos horizontes. A continuación, se observan algunas imágenes de las plazas y monumentos en las calles de Santiago producidas en noviembre de 2019: 
Museo de la Dignidad: entre la polémica y la memoria.Una mirada

Dossier sobre las acciones artístico-políticas en el octubre chileno de 2019

Imagen 11. Imagen del Cerro Santa Luzia resignificado de Cerro Huelen y Carteles con dibujo de Camilo Catrillanca

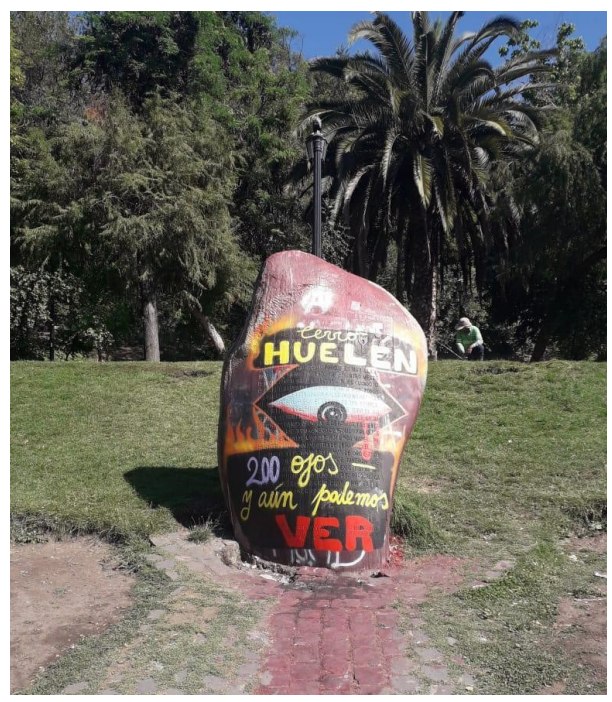

Fuente: Teresa Oliveira (noviembre 2019).
Imagen 12. Imagen del Cerro Santa Luzia resignificado de Cerro Huelen y Carteles con dibujo de Camilo Catrillanca

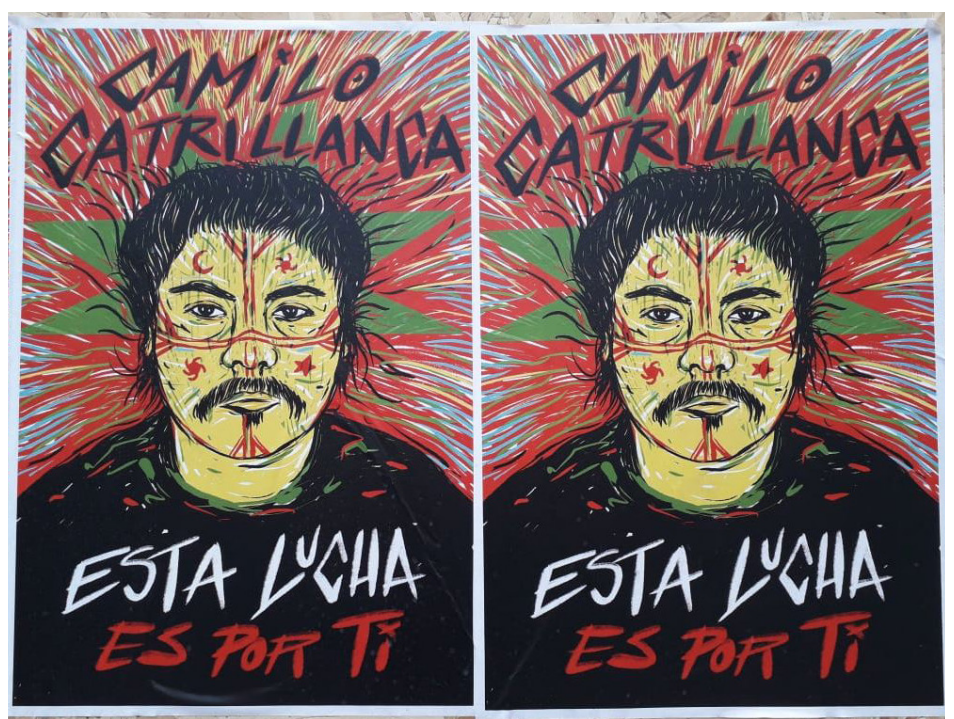

Fuente: Teresa Oliveira (noviembre 2019).
Imagen 13. Imágenes de monumentos ocupados en Santiago

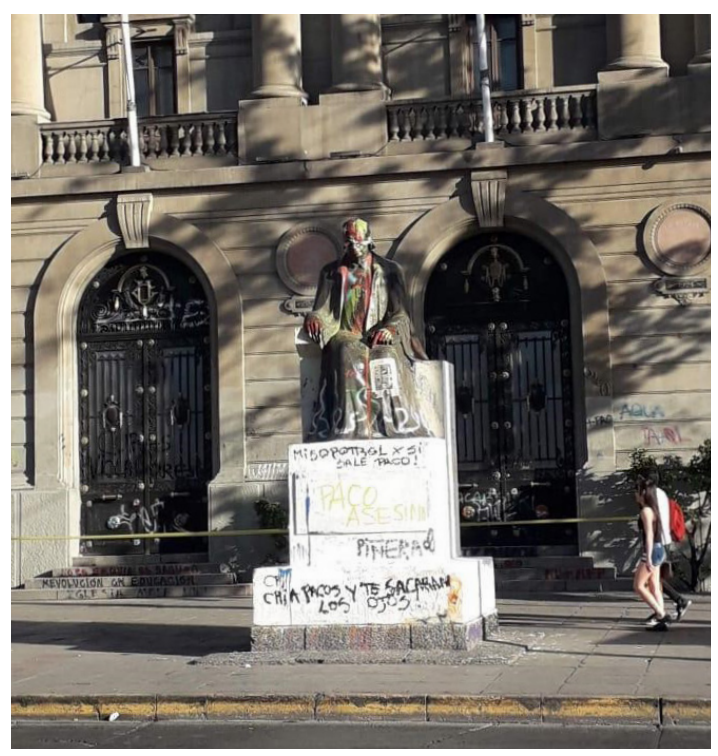

Fuente: Teresa Oliveira (noviembre 2019).
Imagen 14. Imágenes de monumentos ocupados en Santiago

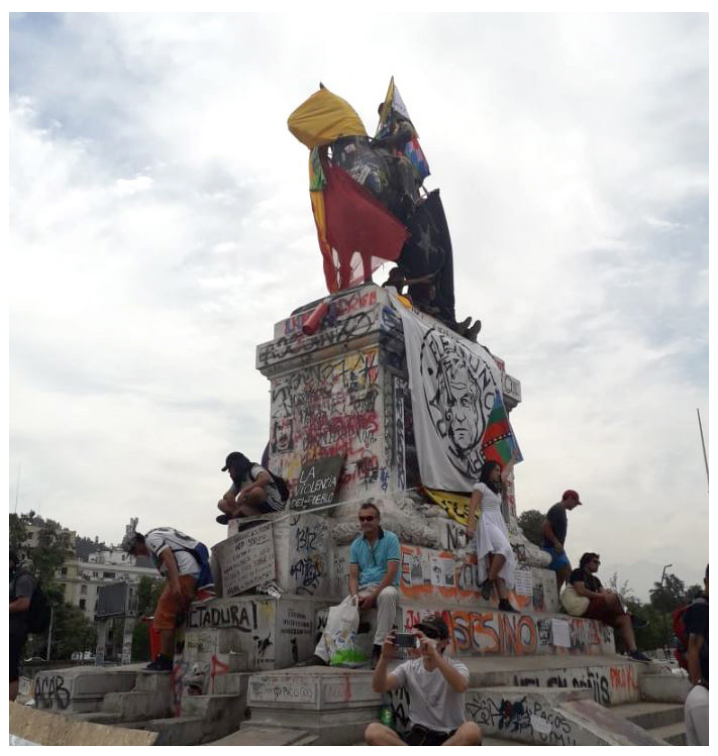

Fuente: Teresa Oliveira (noviembre 2019). 
Por lo tanto, la acción artística Museo Dignidad que pretendemos discutir a continuación tiene como telón de fondo la manera cómo los movimientos de transformación social que surgieron en octubre de 2019 se presentaron simbólicamente en la esfera pública chilena. El profundo proceso de cuestionamiento del pacto social actual, llevó al cuestionamiento simbólico de los monumentos e instituciones de Cultura que lo representan y articulan preguntas que van desde la esfera de lo económico y lo político, hasta la relación entre arte y campo artístico en Chile. Para lograr profundizar en la comprensión de la relación entre el arte y la política desde ese lugar de exterioridad institucional que es la calle, es importante entender que, en Chile, existe una importante tradición de producción de arte callejero político, cuestión a que apuntaremos, brevemente, en la siguiente sección.

\section{Arte callejero y acción política en Chile: antecedentes}

\section{Arte callejero chileno: entre la gráfica y la propaganda}

Tal como lo dijimos anteriormente, la presencia de imágenes y consignas en los muros de la ciudad no es una novedad histórica en Chile. Desde inicios del siglo XX, la relación entre arte y comunicación (arte gráfico) se viene gestando, no sin conflictos o rupturas (Espinoza, 2004). La historia del cartel chileno se confunde con la historia del arte callejero o de la intervención artística urbana en los muros de la ciudad, superponiendo la gráfica, la propaganda política y la acción estético-ética. Al interior de esa historia, el movimiento de las brigadas muralistas de fines de la década de 1960 e inicios de la de 1970 fue el que más impactó en el imaginario de la intervención mural urbana en Chile. El muralismo chileno influenció una generación de artistas y productores culturales, lo cual dejó importantes legados para el arte callejero local. Las brigadas muralistas generaron una identidad visual propia que marcará la producción artística de la época y es constantemente comparada con el movimiento muralista mexicano por su influencia estética, el carácter colectivo de las acciones y la búsqueda por la masividad de las obras. Sin embargo, esa no es la única influencia de ese movimiento.

Según el historiador Eduardo Espinoza (2004), además del muralismo mexicano, es necesario relevar otra gran influencia del movimiento de las brigadas artísticas chilenas: el diseño gráfico. La razón de eso se debe a que el período en el que las intervenciones en los muros de las ciudades se empezaron a realizar de manera más sistemática, tuvo relación directa con la propaganda política de los partidos de izquierda articulados en torno a la Unión Popular, especialmente el Partido Socialista y el Partido Comunista. De este modo, gran 
Museo de la Dignidad: entre la polémica y la memoria.Una mirada

Dossier sobre las acciones artístico-políticas en el octubre chileno de 2019

parte de las acciones de intervención urbana mural de la época se relacionaban a objetivos propagandísticos claros, en los cuales la comunicación efectiva y directa del mensaje político era el principal logro buscado. En resumen, es posible afirmar que el proyecto de la Unión Popular y la participación social fueron aspectos cruciales en la producción cultural de la época y que influenciaron la acción de artistas e intelectuales. Teniendo en cuenta este aspecto, es valioso observar la historia del cartel chileno para encontrar la escisión que facilita la comprensión de los caminos que tomó el arte gráfico y el movimiento muralista en Chile.

Espinoza (2004) también señala que los procesos que dieron origen a la antigua Escuela de Artes Aplicadas y su vinculación a la Universidad de Chile ocurren en un momento (década de 1930) en el cual la imprenta nacional ya se configuraba como una industria en plena actividad, con capacidad para formar su propio personal de manera autónoma. Consecuencia de ello, según el autor, es que los profesionales formados por la Escuela de Artes Aplicadas terminaban en desventaja técnica respecto de los formados en el área de publicidad, relacionada directamente con la imprenta. Pero, además de eso, había una segunda diferencia entre estas dos clases de profesionales que se hará bastante relevante en los años posteriores:

Mientras el circuito publicitario local tuvo como mayor influencia el dibujo comercial estadounidense -que además de las agencias tuvo visibilidad en el medio gracias a publicaciones internacionales como Selecciones del Reader's Digest-, Artes Aplicadas dio cabida a ejercicios que tuvieron como importante tema de estudio la artesanía tradicional y la visualidad proveniente de los pueblos originarios (Espinoza, 2004, p. 4).

Esta diferencia en términos de elecciones estético-técnicas en el interior de la producción gráfica chilena llevó a que, durante la década de 1960, junto con la profesionalización del medio y la masificación de la publicidad visual, surgiera la demanda por la politización de este sector. La complicidad entre el diseño gráfico y la propaganda política producida en este momento por las brigadas muralistas es donde reside el nexo entre el arte callejero, la intervención urbana chilena y el cartel. Para Espinoza (2004) , el diseño ejerció importante influencia en las brigadas muralistas e interfirió tanto en sus modos de producir (colectivamente, sin énfasis en la autoría individual) como en la producción misma (las tipografías de las letras utilizadas en los mensajes, los colores, trazos y dibujos producidos). Además, los diseñadores fueron también influenciados por la atmósfera político-ideológica del momento. En este movimiento de retroalimentación, las piezas gráficas producidas en talleres de artistas gráficos, como el 
famoso taller de los hermanos Larrea, poseían características similares a las de las imágenes que circulaban en los muros de la ciudad.

Esa doble influencia tenía que ver, según Espinoza, tanto con la precariedad de recursos, que terminaba por asemejar algunas soluciones estéticas como el uso del trazado negro, sino que también respondía a la escisión entre el ámbito publicitario comercial y el académico, donde los artistas gráficos egresados de este último, en general, se acercaban a un deseo político de producir "algo distinto" (Espinoza, 2004). El deseo de involucrarse en procesos de transformaciones político-sociales o de distanciarse de un lenguaje publicitario meramente comercial fue la marca de la participación social de algunos artistas gráficos del período. El deseo de participación social de artistas visuales y gráficos y su involucramiento en el proyecto de cambio de la Unidad Popular, marcó lo que las autoras Javiera Manzi y Nicole Cristi (2017) definieron como el período de la "utopía gráfica".

\section{De las brigadas muralistas a los carteles: el arte de izquierda y sus reconfiguraciones}

Como se mencionó anteriormente, el proceso de formación de las brigadas muralistas en Chile respondió, de manera más inmediata, a la necesidad de búsqueda de medios alternativos para realizar la comunicación directa y la adhesión de los sectores populares y trabajadores al proyecto de creación de la vía socialista en Chile. Específicamente, se trató igualmente de hacer propaganda política de la campaña de Allende como candidato de la Unión Popular. En ese momento (finales de la década de 1960) los partidos socialista y comunista (PS y PC) eran los principales articuladores de acciones colectivas murales, cuya misión inicial era la de comunicar consignas de los partidos y provocar la guerra informacional con la prensa oficialista de derecha (Rodríguez-Plaza, 2003; Espinoza, 2004).

Es importante, en este punto, hacer una mención más detenida al proyecto político de la Unión Popular (UP). El gobierno popular planteado por esta coligación de izquierda no solamente pretendía promover una alternativa al gobierno oligárquico. Más bien, se trataba de un proyecto de transición pacífica del país a la vía socialista, proceso que pretendía reformular el Estado y la sociedad desde nuevas bases ideológicas. De ahí que todos los sectores de la sociedad involucrados en el proyecto (además de los partidos políticos), especialmente los artistas, los intelectuales, los estudiantes universitarios y los trabajadores de la cultura, se convirtieron en una fuerza importante en la construcción de esta nueva sociedad y del "nuevo hombre" que esta necesitaba. 
Museo de la Dignidad: entre la polémica y la memoria.Una mirada

Dossier sobre las acciones artístico-políticas en el octubre chileno de 2019

En gran parte, la riqueza de producciones culturales de ese período está asociada al proyecto socialista de la UP y enfocada en fundar una nueva cultura crítica en el país. El período vio el surgimiento de importantes movimientos culturales como el de la Nueva Canción chilena ${ }^{4}$ y el Nuevo Cine chileno ${ }^{5}$ que impulsaron una gran producción musical y audiovisual crítica, cuyas obras, en su mayoría, son consideradas marcos de la producción artística de izquierda del país. Como resultado de esta efervescencia cultural, fueron creados también sellos musicales y editoriales, a ejemplo de la famosa editorial Quimantú (sol del saber). En esta línea, la antigua editorial Zig Zag, tras presentar graves problemas económicos, fue comprada por el Estado a través de Allende y pasó a ser administrada por los trabajadores quienes fueron responsables por una gran producción de carácter popular, masivo y educativo6 (Molina, Facuse \& Yáñez, 2019). La idea central que animó la acción de artistas y militantes políticos era construir una cultura donde el pueblo fuese sujeto y productor activo de los bienes culturales, emancipados y críticos de su condición social.

Lo anterior revela qué concepción del arte y de lo artístico estaba en juego, informando las prácticas de los agentes culturales que animaron el proyecto cultural de izquierda del período ${ }^{7}$. La idea del arte subyacente en ese proyecto era aquella cercana a la noción marxista de emancipación, o sea, de reconocimiento de los procesos ideológicos de falsificación de lo real realizados por la minoría burguesa para revelar la verdad a la clase proletaria explotada. Según el historiador Martín Bowen: "para el arte y la cultura en transición al socialismo, la búsqueda de la verdad pasaba por una asimilación con lo que se consideraban los intereses

${ }^{4}$ El movimiento de la Nueva Canción chilena, en el cual jugó un rol importante la cantante Violeta Parra y destacaron también artistas como Víctor Jara, los grupos Inti Illimani y Quilapayún, generó un importante proceso de creación de sellos musicales y de producción gráfica de izquierda en Chile en ese período.

5 "En Chile los mayores intérpretes de esas premisas fueron Miguel Littin, Helvio Soto, Aldo Francia y, en un estilo más corrosivo, Raúl Ruiz, además de los documentalistas Pedro Chaskel y Patricio Guzmán" (Biblioteca Nacional de Chile, s.f).

6 "El desafío planteado por los directivos de Quimantú y la Unidad Popular fue cumpliéndose en el corto plazo. En 1972, en la mayoría de los kioskos del país se encontraban las publicaciones de esta editorial, hecho que no tiene precedentes en la historia editorial chilena" (Biblioteca Nacional de Chile, s.f).

7 Esa concepción del arte y de lo artístico del período de la UP se enmarca en lo que Rancière (2005) define como régimen ético de las artes, cuestión que será profundizada en el próximo apartado.

ESCENA. Revista de las artes, 2021, Vol. 80, Núm. 2 (enero-junio), pp. 253-296 
de la clase proletaria" (Bowen, 2008, p. 4). Esta búsqueda de la verdad por la emancipación crítica y por la educación, presente en el gobierno popular y en los movimientos artísticos del período, tendrá como características la tendencia a la masividad, la búsqueda por la autenticidad (la identidad chilena auténtica) y la producción de disputas informacionales (iconográficas, simbólicas y textuales).

Este dato es importante para comprender de manera más clara el rol de las brigadas muralistas en el contexto del arte político (o de izquierda) del período. Las pinturas murales, trasladaron los carteles a los muros (Espinoza, 2004) para ampliar su dimensión, es decir, para tornar masivo el mensaje con la finalidad de alcanzar el máximo número de personas posible; era la contribución iconográfica para el proyecto de construir una nueva cultura crítica que se alimentaba de los flujos de la ciudad. El tránsito de personas era un dato fundamental para la acción brigadista que utilizaba los espacios más visibles y frecuentados para hacer llegar la imagen del Nuevo Chile que se pretendía construir en ese momento. De ahí que los muros a pintar fuesen estudiados y el sector de Plaza Italia (principal punto de conexión entre los sectores ponientes y orientes de la ciudad) era el privilegiado para dejar los mensajes (Rodríguez-Plaza, 2001, 2003).

Históricamente, las brigadas formadas en ese período que más se destacaron por sus acciones murales fueron las Brigadas Ramona Parra (PC) y la Brigada Elmo Catalán (PS) (Rodríguez-Plaza, 2001, 2003; Dalmás, 2007). La organización de ambos movimientos se estructuró a partir del trabajo colectivo, desde las organizaciones juveniles, coordinado y supervisado por militantes destacados de los partidos. La Brigada Ramona Parra, la primera en formarse, fue dirigida por Alejandro "Mono" González, quien quedó conocido no solo por la organización de las tareas de propaganda de la brigada, sino también por "la dirección artística de los murales" (Dalmás, 2007).

De acuerdo con la investigadora Carine Dalmás (2007), la Brigada Ramona Parra (BRP) se destacó por sus dibujos a gran escala que hacían amplio uso del trazo negro como contorno, generalmente pintados con colores fuertes, especialmente el azul, el rojo y el amarillo. Otro dato importante revelado por la autora se refiere al proceso de división del trabajo al interior de las brigadas, el cual era previamente organizado antes de la salida a las calles a pintar. El trabajo se estructuraba a partir de las distintas habilidades técnicas de cada miembro, de manera que se diferenciaban roles: los que preparaban los muros, pintando el fondo blanco para los dibujos; los que se encargaban de escribir los textos de los mensajes (especialidad reservada a los que presentaban mejor habilidad tipográfica) y 
Museo de la Dignidad: entre la polémica y la memoria.Una mirada

Dossier sobre las acciones artístico-políticas en el octubre chileno de 2019

los que realizaban los contornos de las imágenes (tarea exclusiva de los con mejor habilidad para el dibujo), mientras los demás las llenaban con pintura. También había encargados de vigilar y de coordinar todo el equipo (Dalmás, 2007).

Del lado de la Brigada Elmo Catalán (BEC), las formas de estructuración y organización del trabajo de propaganda mural fueron semejantes al de la Brigada Ramona Parra. Las diferencias que se produjeron entre la BEC y la BRP se empezaron a hacer más visibles en el período post-1970, cuando ambas brigadas desarrollaron la dimensión estética más profundamente, y en el período de la lucha por la permanencia del gobierno popular, cuando, según Dalmás, las disidencias entre el PC y algunos militantes del PS relacionadas con la lucha popular se hicieron más evidentes en las consignas expuestas en las calles.

En términos estéticos, es importante destacar la producción de una imagética original en el proceso de ocupación sígnica de la ciudad por las brigadas muralistas. Debido a la precariedad de materiales, el poco manejo técnico de gran parte de los brigadistas y la velocidad con que se tenían que producir los murales, los dibujos simples y ligeros eran la característica central de estos murales. El contorno negro, con el que se corregía imperfecciones de la pintura, se tornó un marco referencial de las pinturas de la Brigada Ramona Parra, por ejemplo, acercándose a la tipografía del período, tal como nos referimos anteriormente (Rodríguez-Plaza, 2001, 2003; Espinoza, 2004; Dalmás, 2007).

En relación con la elección de los símbolos e imágenes, estas respondían principalmente a intereses comunicacionales. Sin embargo, en algunos casos, produjeron imágenes íconos como la paloma, el puño cerrado, la mano abierta, la mujer representando la tierra y la fertilidad, los trabajadores, etc. (Dalmás, 2007) Algunos de los murales de la Brigada Ramona Parra (BRP), especialmente los producidos en el período post-1970, presentaban una producción figurativa más cercana a la estética muralista mexicana, a pesar de explotar bastante los colores, especialmente el rojo y el amarillo. Los colores fuertes tenían la intención de acercar los murales a las producciones artísticas populares y a una visualidad andina que permiten su pronto reconocimiento. Sin embargo, diferente de las pinturas murales mexicanas, donde el sujeto original de la historia y la nación se convirtió en el indígena, en los murales de Chile la identidad nacional no se amparó necesariamente en la figura del indígena o del pasado (los pueblos tradicionales), sino que buscaba crear una imagen del pueblo como una amalgama en torno del proyecto socialista de la UP. La relación con la cultura andina, que se dejaba ver a través de las formas de las figuras o la elección de los colores, cumplía objetivos pragmáticos en el sentido de conformar una visualidad reconocible y asociada a esa noción de popular buscada por el proyecto socialista.

ESCENA. Revista de las artes, 2021, Vol. 80, Núm. 2 (enero-junio), pp. 253-296 
En resumen, las brigadas muralistas en Chile fueron responsables por la creación de una iconicidad y visualidad propias que alimentaron el imaginario de izquierda y de lucha social local, en estrecha vinculación con la ocupación del espacio urbano. El desarrollo del muralismo chileno, cercano al desarrollo del arte gráfico y de la producción de carteles de propaganda del gobierno, a través de los diseñadores asociados a la Unión Popular, marcaron la producción de una estética callejera y política en Chile. De este modo, tal como definió el investigador Patricio Plaza (2001), el movimiento de las brigadas representó una "picturalidad" responsable no solo por representar, sino más bien por crear el imaginario popular de izquierda del período. Esa acción colectivista, con objetivos comunicacionales y educadores, estableció una manera de producir y ocupar artísticamente el espacio público compartida orgánicamente entre militantes, estudiantes, artistas, artistas gráficos, pobladores y transeúntes. Rápidamente, esa forma de producción se ramificó en la creación de distintas otras brigadas (Camilo Torres, Chacón, Inti Peredo), se trasladó a otros formatos y soportes, e incluso llegó hasta los días actuales como un legado de la acción político-artística callejera de ese período.

\section{Resistencia gráfica: el período Pinochet}

El conflicto político producido desde el inicio del gobierno popular de la UP intensificó la producción de las brigadas que orientaron su trabajo a la defensa de Allende y del gobierno popular. Consumado el golpe, en 1973, varios miembros de estas brigadas pasaron a ser perseguidos y toda la producción iconográfica y propagandística del período (carteles, publicaciones, murales) pasó a ser destruida con virulencia comparable a la de la destrucción de los cuerpos de militantes y perseguidos políticos. De manera casi inmediata tras la deposición violenta de Allende, la junta militar declaró cancelada la constitución vigente hasta entonces y decretó el veto a lo que consideraron "propaganda subversiva" (Cristi \& Manzi, 2017).

La persecución a los productores culturales (intelectuales, artistas, militantes, pobladores) y a las producciones (censura de películas, músicas y publicaciones, borramiento de murales, cierre de exposiciones) fue la dimensión simbólica de la represión al proyecto de la UP. Esta situación provocó un proceso que fue denominado por varios autores como "apagón cultural" chileno. La violencia de esta persecución a las artes y a la cultura de izquierda en Chile fue sentida en todos los sectores (el terrible asesinato de Víctor Jara es una muestra de ello), fue en el espacio urbano donde quizás se experimentó de manera más visible el golpe de ese intento de borramiento cultural. Ejemplo de ello es la "operación limpieza" 
Museo de la Dignidad: entre la polémica y la memoria.Una mirada

Dossier sobre las acciones artístico-políticas en el octubre chileno de 2019

(Cristi \& Manzi, 2017), una acción que contó con el apoyo de civiles para pintar de blanco varios de los murales de las brigadas, así como para encubrir a muchos de los carteles que ocupaban los muros por todas las calles y avenidas de la ciudad de Santiago. La producción gráfica también fue duramente perseguida y varios carteles y afiches fueron destruidos tanto por funcionarios del Régimen Militar como por particulares que temían ser flagrados portando tales piezas gráficas:

De este modo, la violencia desnuda de la investida militar que persiguió, torturó, ejecutó e hizo desaparecer a miles de personas, tuvo como correlato la violencia simbólica de un régimen que extirpará todo signo y rastro visible de la izquierda en el espacio público. Los primeros dos años representaron a nivel cultural "la desinfección del pasado marxista y, por otra, la promoción de una noción militarizada de la estética cotidiana, que se refleja en rasgos tales como la depuración, el orden y la restauración fervorosa de los símbolos patrios" (Errázuriz y Leiva, 2012, p. 15). La ciudad de Santiago, como tantas otras localidades a largo de Chile, se acercó catastróficamente a la imagen que anticipó Ana Cortés cuando, en pleno desarrollo del afichismo en Chile, planteó que "una ciudad sin gritos pegados en los muros sería hoy en día casi una ciudad silenciosa” (1937) (Cristi \& Manzi, 2017, p. 5).

Sin embargo, la estrategia de resistencia a ese proceso de censura y represión profundas no tardó en aparecer. Según, nuevamente, Nicole Cristi y Javiera Manzi (2017), autoras de una seminal investigación sobre la resistencia gráfica en Chile durante el período de la dictadura de Pinochet, para hacer frente a la persecución y a la represión política del momento, las grandes pinturas murales o los afiches de gran porte fueron sustituidos por formatos más pequeños como folletos y carteles. Las nuevas agrupaciones artísticas que surgen entre mediados y finales de los años setenta como, por ejemplo, la Asociación de Plásticos Jóvenes (APJ) y el Taller Sol, serán responsables de dar nueva cara a estos materiales.

La contribución gráfica de estos grupos en la producción de afiches para las protestas se suma a la construcción de una importante red colaborativa que se establecía entre los pobladores, trabajadores, artistas y operadores de las gráficas para la producción de una visualidad de resistencia que adquirió un carácter particular. La iconografía de la resistencia a la dictadura se caracterizaba por el uso de algunos símbolos comunes a la iconografía muralistas (el puño cerrado, la imagen del trabajador, la paloma, entre otros). Pero, de manera distinta a la estrategia de las brigadas, la producción de los afiches estaba directamente condicionada a demandas más específicas y resentía de las condiciones de precariedad y represión política intensas.

ESCENA. Revista de las artes, 2021, Vol. 80, Núm. 2 (enero-junio), pp. 253-296 
En otras palabras, a diferencia del período de fines de 1960 hasta 1973 -en el que los trabajos fueron financiados en gran medida por el Estado (gobierno UP) y algunos talleres como el de los hermanos Larrea se hicieron famosos, marcando una autoría/identidad en las producciones-, durante la resistencia, las organizaciones que solicitaban los afiches ejercían una influencia directa en la producción de estos. De esto resultó la realización de un trabajo conjunto entre los artistas y los sindicatos y otras organizaciones quienes definían las consignas (y a veces hasta las imágenes y formatos). Ese tipo de estrategia de acción produjo lo que los artistas del período nombraron como "afiche abierto". Siguiendo a Cristi y Manzi, "mediante esta operación, el afiche no funciona como soporte de un enunciado fijo y previamente definido, sino más bien como un espacio en blanco para ser intervenido, significado y apropiado por las comunidades" (Cristi \& Manzi, 2017, p. 10).

Por su parte, es necesario resaltar, nuevamente, el hecho de que la contingencia política sometía el trabajo producido por estos grupos a un contexto de "constante apremio" (Cristi \& Manzi, 2017), tanto por la velocidad exigida por los encargos de las comunidades como por el miedo a ser detenido, y de precariedad. Estas condiciones llevaron al desarrollo de experimentaciones variadas en la producción gráfica a partir de la creación de estrategias tanto para ampliar la reproducción de materiales (incluyendo en ello la socialización del conocimiento de la producción gráfica) como para profundizar el impacto de las piezas en el espacio público. De este modo, el uso de colores más oscuros, la integración de textos a imágenes, el uso de materiales y procedimientos más baratos, además de los formatos reducidos, marcó la estética de los carteles del período. Un interesante ejemplo de la producción de esta época es la serie realizada por la APJ "Serie 1984", la cual se componía de 27 pliegos de $45 \times 35 \mathrm{~cm}$ cada uno que formaban, al ser dispuestos en conjunto, una obra en escala mural (Cristi \& Manzi, 2017).

Si bien las diferencias entre estos períodos son significativas, eso no implica que no haya habido continuidades entre ambos. Un ejemplo de ello es la búsqueda por producir colectivamente y por involucrar a los sectores populares en la creación artístico-política de los materiales utilizados en las protestas y reuniones comunitarias. Este es un importante elemento que acerca la resistencia gráfica de fines de los años 1970 y década 1980 al proyecto de liberación popular de la UP de los años anteriores.

No obstante, la principal permanencia entre un período y otro es la utilización de la calle como espacio privilegiado, tanto física como simbólicamente, para librar una lucha informacional contra la represión política de la dictadura. Todas las agrupaciones de artistas, 
Museo de la Dignidad: entre la polémica y la memoria.Una mirada

Dossier sobre las acciones artístico-políticas en el octubre chileno de 2019

estudiantes y comunidades tenían como fin ocupar la calle, ahora clandestinamente, para denunciar los desaparecidos, para clamar justicia por los detenidos y para informar a la población sobre los desmanes del gobierno militar. Estas ocupaciones clandestinas de las calles con afiches, carteles y pancartas durante toda la década de 1980 fueron el símbolo de la resistencia y la principal vía comunicacional de los sectores insurrectos.

"Las trincheras gráficas" (Cristi \& Manzi, 2017) creadas en ese momento y su éxito en producir piezas gráficas con técnicas artesanales, en gran velocidad y utilizando materiales baratos, son elementos que se harán visibles nuevamente en las prácticas políticas post-dictadura en Chile. Las protestas estudiantiles de inicios del siglo XXI harán renacer muchas de estas prácticas gráficas colectivas, políticamente autónomas y característicamente artesanales. Varios colectivos gráficos surgen durante los períodos de revuelta estudiantil, entre el 2006 y el 2011, tales como "Taller de Serigrafía Instantánea, Estudiantes por Chile, el Taller Mano Alzado, la Brigada de Propaganda Feminista, Seri-Insurgentes, y Ser \& Gráfica" (Cristi \& Manzi, 2017, p. 14).

Por tanto, es esta memoria de ocupación político-artístico-gráfica de los muros de Santiago el archivo subyacente de la actual explosión artística producida tras el estallido social del 18 de octubre de 2019. Sin embargo, el actual fenómeno llama la atención por la potencia estética y por la diversidad de referentes, donde destaca la influencia de la cultura urbana cosmopolita, una imagética basada en la industria mediática y un importante enfoque en la circulación por las redes sociales (Jara, 2019, Salinas 2019). El uso del graffiti y técnicas del arte callejero que emergen desde la cultura del hip hop, además de acciones relacionadas con el arte contemporáneo, se mezclan con referentes de la cultura popular y el grabado de la década de 1960, generando un intenso mosaico de imágenes y performances tanto callejeras como digitales. Por lo anterior, es útil destacar que, a pesar de la especificidad del momento actual, todavía cobra importancia la memoria de la intervención política gráfica en Chile, tal como se observa en varios de los actuales graffitis, stencils, afiches y consignas.

Finalmente, es necesario subrayar también que la actual ocupación masiva de los muros y la diversidad de materiales, estilos y formatos que presenta, no cuenta con la organización y objetividad de los períodos anteriores. La actual revuelta social en Chile se produjo no solamente a partir de colectivos organizados en torno a un objetivo político (sea partidario, sea autónomo, pero con pautas y objetivos reconocibles), sino que, principalmente, a través de un aglomerado de sujetos que autónoma y anónimamente ocupó con

ESCENA. Revista de las artes, 2021, Vol. 80, Núm. 2 (enero-junio), pp. 253-296 
consignas, fotos, carteles y pinturas los muros de la ciudad. Tal vez sea ese aspecto lo que configura la principal diferencia entre la actual revuelta en Chile y los períodos anteriores de protestas y movimientos políticos, además de impactar en la producción de la visualidad vasta y rebelde que la acompaña, tal como se mencionó anteriormente. Es en ese contexto que se realiza la acción Museo de la Dignidad, objetivo central de este artículo.

\section{El Museo de la Dignidad: la acción y sus efectos}

\section{Cuestiones metodológicas}

La investigación realizada sobre el Museo de la Dignidad buscó analizar los efectos de la acción en la esfera pública tanto en su dimensión "real" (la calle y los muros) como en su dimensión "virtual" (las redes sociales, artículos publicados online, imágenes digitales). De este modo, es posible dividir el proceso de investigación en dos momentos, que exigieron distintas estrategias metodológicas: 1) Observación participante in situ; 2) Observación participante virtual.

La primera parte de la investigación se concentró en la observación directa de las piezas enmarcadas y los cambios producidos en estas con el pasar del tiempo. Se realizaron recorridos fotográficos por los lugares elegidos para las molduras, con el fin de percibir las obras en su emplazamiento territorial y las reacciones de los transeúntes a ellas. Los locales elegidos, en general, fueron aquellos de mayor flujo de personas, emplazados en los principales puntos de conflicto en el área que, a partir de las protestas, se conoce como "Zona Cero". Los locales fueron visitados durante diciembre de 2019 y enero de 2020 y se buscó fotografiar las mismas piezas en los distintos períodos de tiempo.

La segunda parte de esta investigación ocurrió de manera simultánea a la primera, pero se divide el proceso con el fin de una mejor comprensión de las distintas estrategias empleadas. En ese segundo momento, se buscó observar la presencia de la acción en las redes sociales, observando sus páginas (especialmente en Instagram), la reacción a los contenidos producidos y las publicaciones y comentarios realizados por la prensa y usuarios de las redes sociales sobre la acción. De este modo, se buscó producir una observación virtual del impacto del Museo de la Dignidad en la esfera pública, tomando en consideración que la internet y las redes sociales han conformado formas de sociabilidad relevantes en el período actual, llevando a la emergencia de métodos de estudios como la etnografía virtual para analizarlos (Ardèvol, Bertrán, Callén \& Pérez, 2003). El segundo momento de 
Museo de la Dignidad: entre la polémica y la memoria.Una mirada

Dossier sobre las acciones artístico-políticas en el octubre chileno de 2019

la investigación se prolongó en el tiempo hasta el momento de producción de este artículo y seguirá realizándose, ya que la acción sobrevivió a las intemperies de la contingencia sanitaria de la pandemia del nuevo coronavirus a través de sus redes digitales.

Los distintos momentos de investigación generaron, hasta el presente momento, un corpus de análisis que contiene: 24 imágenes (diez fotografías in situ realizadas por las investigadoras y catorce imágenes recolectadas desde fuentes digitales como la página de Instagram del proyecto), ocho artículos publicados en la prensa local sobre el proyecto y dos prints de publicaciones en páginas de usuario de redes sociales que expresaron opinión sobre el proyecto.

Es importante mencionar que el presente artículo realiza análisis preliminares a partir del material inicial conseguido hasta el momento. Los efectos de la emergencia sanitaria producida por el nuevo coronavirus se hicieron sentir también en el desarrollo de la investigación, al inviabilizar la realización de otras acciones de recolección de datos. De tal manera, se espera proseguir esta investigación posteriormente y añadir al corpus de trabajo cerca de catorce entrevistas en profundidad: siete con los miembros del colectivo Museo de la Dignidad y siete con agentes del campo artístico (para mensurar el impacto de la acción al interior del medio artístico chileno).

\section{Análisis de los datos}

El análisis realizado en este artículo se basa en el método del Análisis de Discurso Crítico, tal como elaborado por Norman Fairclough (2001). El objetivo es analizar los documentos, enfatizando las prácticas discursivas, simbólicas y sociales puestas en acción por la performance producida por el proyecto Museo de la Dignidad.

En este trabajo, el Museo de la Dignidad será tomado como una práctica estético-discursiva que produce efectos en la esfera pública donde ejerce su acción. De este modo, los testimonios de los integrantes del grupo, retirados de artículos publicados online, no serán considerados en su dimensión subjetiva individual, sino que serán analizados como elementos discursivos que insertan sentidos en la acción, la cual, en su existencia en el espacio público, confronta otros signos y discursos.

Por tanto, la noción de práctica discursiva, tal como es elaborada por Fairclough, constituirá la base teórico-metodológica del análisis de los efectos de producción de disenso (Mouffe, 2014; Rancière, 2009) y reorganización de los regímenes del arte 
(Rancière, 2005) que la acción produce. Según Fairclough (2001), la práctica discursiva debe ser analizada tridimensionalmente, considerando los aspectos textuales (materiales), discursivos y sociales que implican. Esta manera de concebir la práctica como compuesta por diferentes niveles es especialmente útil para analizar la acción en sus dimensiones estéticas, discursivas y sociales, articulando los distintos materiales recolectados para la investigación: textuales, simbólicos, imagéticos y discursivos.

Para realizar el análisis, el corpus fue organizado a partir de la elaboración de categorías que funcionaron como codificadoras de los materiales, con el fin de facilitar el análisis discursivo objetivado. Las categorías responden a las preguntas de investigación planteadas y fueron operacionalizadas de la siguiente manera:

1. Surgimiento de la propuesta: responde a las preguntas sobre ¿quiénes crearon la acción y por qué?

2. Objetivos de la acción: responde a las cuestiones sobre ¿qué pretenden con enmarcar obras callejeras? ¿Cuál es la intención de esa acción?

3. Métodos de acción: responden las cuestiones sobre ¿cómo realizan esa acción? ¿Por qué utilizan marcos dorados?;

4. Criterios de selección: responden a la pregunta sobre ¿cómo seleccionan las obras? ¿Qué criterios utilizan?

5. Impacto en el espacio público: responde a la cuestión sobre ¿qué esperan conseguir? ¿Qué efectos buscan en el espacio público con la acción?

A partir de estas categorías, la acción "Museo de la Dignidad" será observada a partir de los aspectos discursivos, textuales-artísticos (semióticos) y socio-políticos que implica, respetando lo anteriormente discutido sobre el análisis tridimensional que propone Fairclough.

\section{Museo de la Dignidad: una intervención en las intervenciones}

La acción Museo de la Dignidad apareció por primera vez en noviembre de 2019. En el video que circulaba por las redes en ese momento, varias imágenes en blanco y negro de las protestas fueron editadas junto con una música de fondo con sonidos que se asemejan a batidos de baquetas de batería sobre una superfície (recordando el sonido del batido de las ollas, símbolo de las protestas). En medio de las imágenes, se podía leer el siguiente texto: 
Museo de la Dignidad: entre la polémica y la memoria.Una mirada

Dossier sobre las acciones artístico-políticas en el octubre chileno de 2019

El 18 de octubre de 2019 ... En Chile se generó la mayor explosión social de los últimos 30 años ... Una explosión que dio origen a la expresión de cientos de artistas que, inspirados en la revolución, tomaron como arma su arte y como testigo los muros de la ciudad. Presentamos Museo de la Dignidad. Una muestra de arte a cielo abierto que debe quedar para siempre (Museo de la Dignidad, 2019).

El post del video, con fecha de 26 de noviembre de 2019, es el segundo de la página. Definiendo la acción como "causa", el colectivo invita a la participación de la ciudadanía en el proyecto, difundiendo y apoyando las acciones. A partir de ahí el grupo empezó a exhibir una selección de piezas gráficas de variadas técnicas, formatos y autores, en su gran mayoría situadas en la región conocida como "Zona Cero" (cercana a la Plaza Italia), enmarcadas por marcos dorados. La acción en el espacio público logró enmarcar cerca de catorce piezas en las zonas del Centro Cultural Gabriela Mistral, de la Plaza Baquedano (actual Plaza Dignidad) y el famoso Barrio Lastarria (importante punto turístico del centro de Santiago).

Estas piezas pasaron a conformar, por un lado, lo que los autores de la acción calificaron como "una muestra de arte histórica que debe quedar en los muros de la ciudad para siempre" (Museo de la Dignidad, 2019). Por otro lado, fueron reinsertadas en nuevas organizaciones de tiempo y espacio a partir de la intervención de los marcos dorados sobre ellas. Pasaron a conformar nuevas maneras de ver y ser del arte, activando el disenso en los distintos niveles de la organización del sensible (Rancière, 2009) que la acción transfigura y baraja.

En otras palabras, las piezas gráficas enmarcadas por el Museo de la Dignidad son ahora parte de una nueva performance en la esfera pública, participando en las distintas polémicas que esta produce. Los conflictos "institución versus arte callejero", "arte efímero verus arte aurático" y "autoridad cultural versus autonomía creativa" pasan a ser parte de los sentidos de estos trabajos, que dejaron de ser solamente un paste up, una serigrafía o una impresión al ser intervenidos por los marcos dorados. Resumiendo, la intervención del Museo de la Dignidad sobre los trabajos modifica su ser y transfigura su acción en el espacio público, haciéndolos partícipes de un nuevo juego de sentidos.

8 Es interesante recordar que la región de la Plaza Italia era una de las preferidas para realizar acciones murales por las brigadas muralistas, por su localización estratégica en la ciudad. Al pasar de los años, esta región se convirtió en el principal punto de reunión de las protestas realizadas en el país, especialmente en el período democrático (desde inicio de los años 2000).

ESCENA. Revista de las artes, 2021, Vol. 80, Núm. 2 (enero-junio), pp. 253-296 
Imagen 15. Santísima Dignidad (2019), Paloma Rodríguez. Técnica: collage

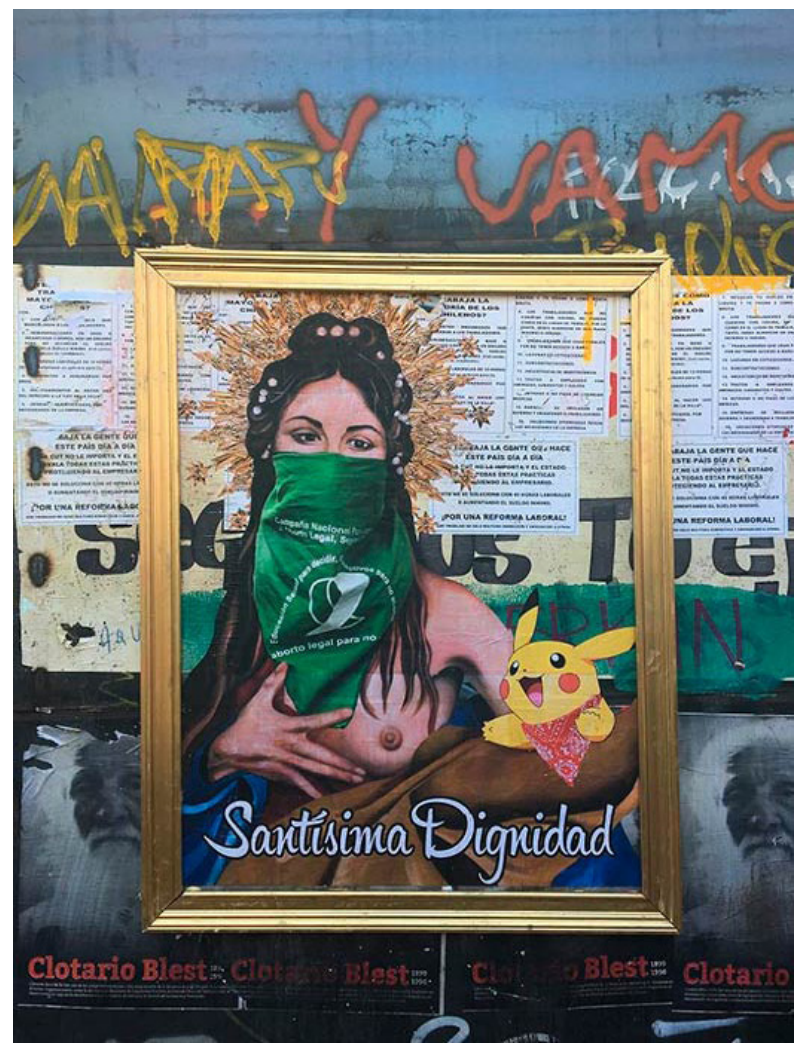

Fuente:Colectivo Museo de la Dignidad.
Imagen 16. Santísima Dignidad (2019), Paloma Rodríguez. Técnica: collage

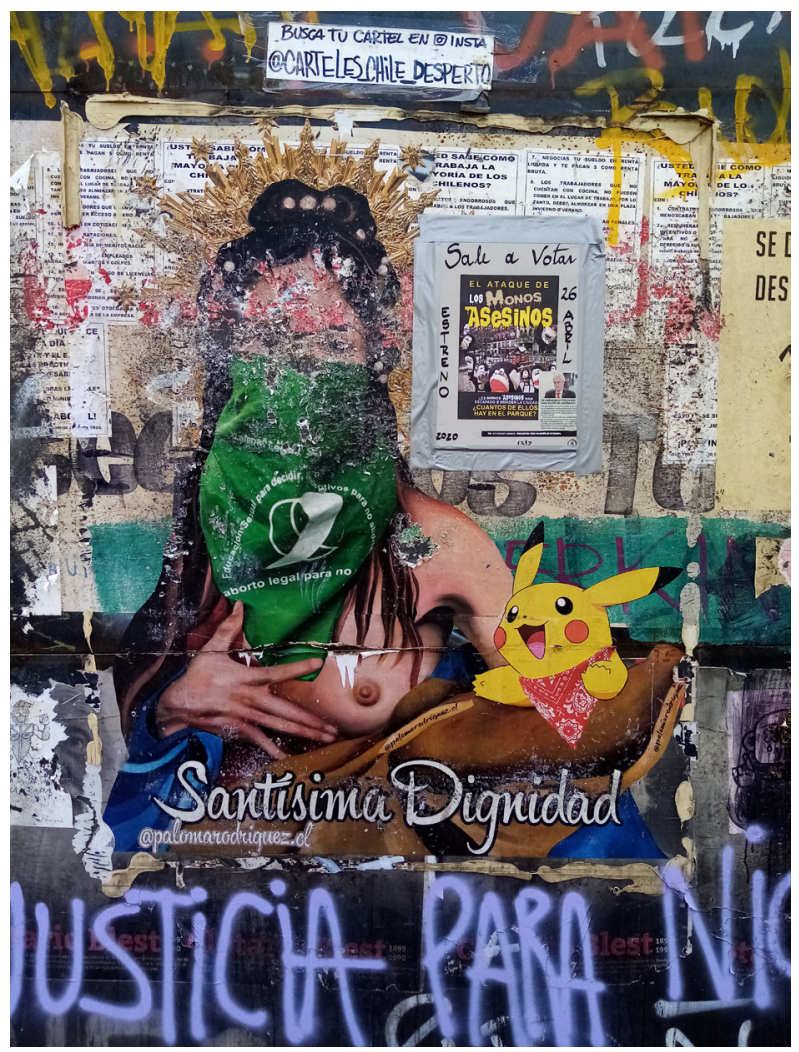

Fuente:Raíza Cavalcanti (enero de 2020).

\section{Museo de la Dignidad versus la esfera pública}

La revuelta social iniciada en Chile el 18 de octubre de 2019, tal como comentamos anteriormente, presenta características bastante particulares en relación con los movimientos político-sociales ocurridos en el país en décadas anteriores. La principal característica es la autonomía en relación a partidos políticos y la búsqueda por la auto-organización colectiva (asambleas barriales, cabildos, colectivos de artistas y estudiantes, coordinadoras feministas, entre otros). Con todo, si bien estas formas de actuación política más autónomas ya se venían dibujando en la esfera pública chilena desde la explosión de las manifestaciones estudiantiles en la primera década de los años 2000, la actual explosión masiva ocurrida desde octubre de 2019 es algo que, hasta el momento, era inédito en el país. 
Museo de la Dignidad: entre la polémica y la memoria.Una mirada

Dossier sobre las acciones artístico-políticas en el octubre chileno de 2019

carácter masivo y difuso, con protestas ocurriendo en varias ciudades del país simultáneamente, es un hecho que ningún movimiento político organizado pudo haber logrado anteriormente. El espontaneísmo de la formación de las manifestaciones se refleja en la multiplicidad de acciones de intervención urbana que se realizaron desde ese momento. Las personas presentes en las calles fueron muchas y varias, así como también fueron muchas las expresiones producidas por estos cuerpos al ocupar el espacio público (las huellas de la multitud).

En la imagen 17, la foto de autoría de Carmen Benito retrata este aspecto masivo de las protestas. La imagen es de la marcha "más grande de Chile", ocurrida el 25 de octubre de 2019, a la cual concurrieron más de un millón de personas, fenómeno jamás visto desde la apertura a la democracia en el país. La foto, emplazada en el muro de protección del edificio de la Telefónica, cercano a la Plaza Baquedano, fue elegida para ser enmarcada por la acción Museo de la Dignidad. Para comprender por qué esa imagen fue elegida, se remite al testimonio de los autores de la acción para la Radio Universidad de Chile, en el cual se comenta la dimensión correspondiente al "criterio de selección":

Imagen 17. Marcha de los 25 mil, Carmen Benito (2019). Fotografía e impresión. Diciembre de 2019

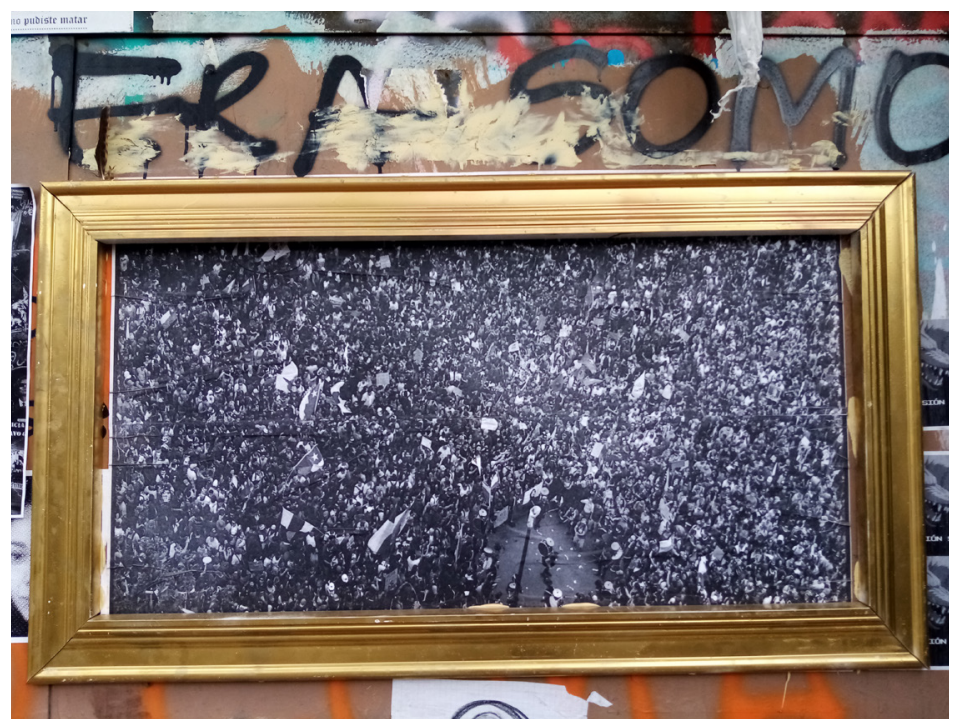

Fuente: Raíza Cavalcanti (2019).
Imagen 18. Marcha de los 25 mil, Carmen Benito (2019). Fotografía e impresión. Enero de 2020

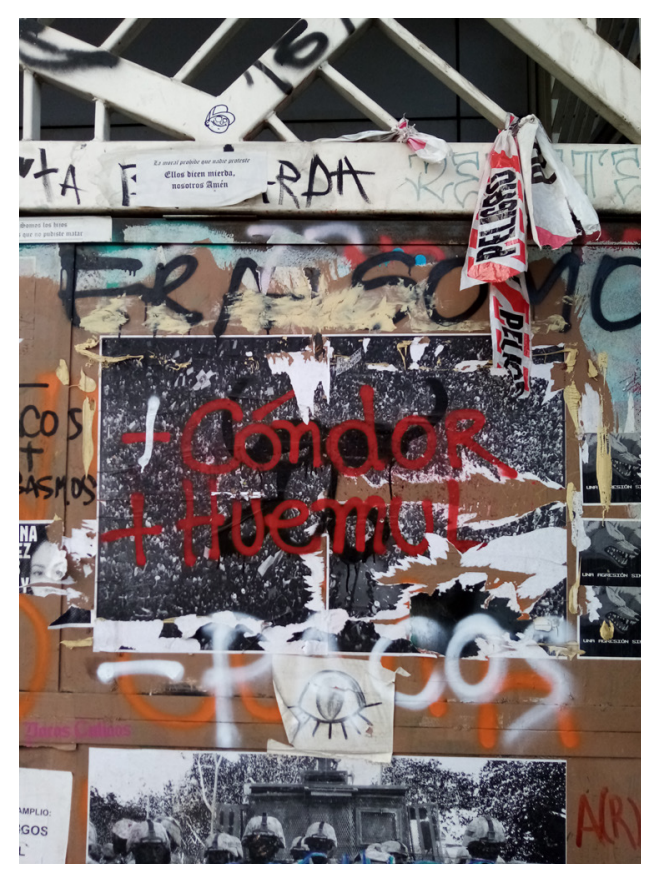

Fuente: Raíza Cavalcanti (2019). 
Uno de los criterios es que sea transversal a cualquier partidismo político, porque creemos que lo que está detrás es la unión de toda la gente en base a un mismo concepto: la Dignidad. Entonces, de alguna forma, se exige eso, pero es una exigencia súper limpia y potente [cursivas añadidas] (Becerra, 2019).

El integrante del colectivo expresa, en esa cita, cómo orienta discursivamente su práctica de selección y encuadramiento de los trabajos; el discurso se elabora desde el plural (creemos). Por lo tanto, el ethos del discurso no es individual, sino colectivo, aspecto que se transmite a la selección de las obras. Es decir que, para ser enmarcados, los trabajos deben expresar esa colectividad (“lo que está detrás es la unión”). El autor del discurso supone una comunidad en torno a la noción de "dignidad" -consigna expresada de manera masiva durante las protestas- y, con base en esta supuesta comunidad, orienta la práctica de selección de piezas que expresen ese imaginario. La imagen de Carmen Benito, entonces, es significada como una expresión de la comunidad: un aglomerado de cuerpos y subjetividades reunidos bajo un objetivo común que corresponde al de exigir dignidad. Quienes están reunidos de manera transversal en esta imagen son la representación del ideal creado por las protestas, el cual es significado por el colectivo: el pueblo unido por dignidad.

Si bien el trabajo de Carmen Benito cumplió las reglas para pertenecer a la "galería a cielo abierto" imaginada por el Museo de la Dignidad, en lo que respecta al impacto en el espacio público, este no presentó el efecto de permanencia previsto. En el discurso de los miembros del colectivo publicado en los periódicos y el de periodistas, el impacto público del Museo de la Dignidad es formulado de manera positiva. Los marcadores de la positividad en el discurso se encuentran en términos como respeto, valorados e intactos presentes en la casi mayoría de los discursos, lo que se puede observar ejemplarmente en las siguientes citas: "cuando pintaron de verde los muros de Providencia, el resto de las obras que había por el sector estaban intactas", cuenta Abufhele sobre el respeto que ha logrado la iniciativa [cursivas añadidas]" (Torres, 2019) y "las personas han valorado el trabajo de los creadores y han respetado el trabajo, sin intervenir sobre las obras y manteniendo en perfecto estado la atractiva galería" (The Clinic, 2019, p.1).

Volviendo a la imagen 17, el deterioro encontrado en la imagen demuestra que la dinámica callejera no siempre confirma la adhesión o el deseo de permanencia (intacto) y respetabilidad que el discurso elaborado sobre la acción proyecta sobre sí. Las fotos analizadas son, la primera, del 14 de diciembre y, la segunda, del 18 de enero. Durante este período de un poco más de un mes, la serie de manifestaciones ocurridas en la Plaza 
Baquedano (ahora conocida como Plaza Dignidad) fueron intensas, especialmente en los días que marcaron aniversarios del "estallido" como el 18 de diciembre y el 18 de enero. La violencia de la represión policial fue respondida con una resistencia virulenta, la cual mezcló momentos potentes de ejercicios creativos con otros donde la destrucción como táctica de protección o ataque eran más evidentes.

Esa dinámica callejera en el epicentro de las protestas evidenció el efímero como condición de existencia en un escenario de conflicto en constante movimiento. Los vaivenes que pasaron a ser típicos en ese punto de la ciudad tales como: reunirse en la Plaza Dignidad; correr para no ser atacado por los policías; articular la primera línea; avanzar con la primera línea, y recuar cuando avanza la polícia, se convirtieron en el modo corriente de habitar ese espacio. Esa manera de ocupar se presenta tanto en los cuerpos como en los muros, monumentos, edificios y signaléticas de la región. Todo se mueve junto con la multitud. Es así que los muros también son llamados a no quedar estáticos y a dar espacio a otros mensajes y voces que, violentamente, irrumpen sobre los materiales anteriormente pegados, los rompen, los rayan y los destruyen.

La destrucción de la imagen de Benito y su marco, más que hablar de una ineficacia de la acción de enmarcar piezas callejeras, remite a la imposibilidad de anular el disenso, tal como Chantal Mouffe (2014) lo elabora y de, manera similar, Rancière (2009): la formación de un consenso -o una nueva comunidad- elimina el disenso y vuelve a borrar e invisibilizar voces, sujetos, cuerpos. El movimiento producido por las constantes protestas impide el consenso, poniendo en evidencia constantemente la dimensión del disenso político (o el agonismo) en las vías públicas. De esa forma, las piezas gráficas presentes en las calles, como voces del disenso, no conforman una totalidad o un consenso en torno a consignas, ya que la masividad, la presencia de sujetos distintos, no permite que una sola voz (o una sola imagen) quede plasmada como ícono de lo común (Rancière, 2009).

Por lo tanto, es importante analizar la destrucción de este trabajo como una evidencia simbólica de que una gran consigna como la "Dignidad", que ha sido constantemente evocada al reunir cuerpos y voces en torno a la lucha contra el neoliberalismo y el estado chileno, no conforma una comunidad total. Esta imagen de la multitud, intervenida por los marcos e insertada al interior de límites que determinaban la unidad de una comunidad, fue nuevamente intervenida, liberada de los marcos, rota y rayada. La multiplicidad, el disenso y el agonismo cobran su presencia e interfieren incluso en la "sagrada dignidad" (o en los intentos de sacralizarla en el espacio público). Ese ejemplo analizado deja en evidencia el

ESCENA. Revista de las artes, 2021, Vol. 80, Núm. 2, pp. 253-296 ISSN 2215-4906 
lado más criticable y criticado del Museo de la Dignidad por algunos agentes del mundo artístico chileno: su verticalidad e intento de institucionalizar el arte callejero.

Volviendo a la cita mencionada anteriormente, retirado del testimonio dado a la Radio Universidad de Chile, se ve que: "Entonces, de alguna forma, se exige eso, pero es una exigencia súper limpia y potente” (Becerra, 2019. Destaque de las autoras). La palabra en destaque "exige" en sí revela una intencionalidad de autoridad: alguien que hace una exigencia. Esta afirmación de autoridad puede llevar a la asociación con las estructuras institucionales de autoridad cultural quienes eligen el buen o mal arte (o que es o no arte). El efecto legitimador de los marcos como producto de la acción del Museo de la Dignidad fue percibido por algunos miembros del campo artístico chileno, quienes expresaron sus opiniones sobre la acción en las redes sociales. Veamos dos ejemplos: "¿Quién determina lo que es digno de ser enmarcado en oro? El lenguaje de la calle, a mi modo de ver, debe estar desprovisto de las lógicas de la selección estética bajo criterios de belleza u otros. Me parece interesante cuestionarlos" (Brodsky, 2019.) y "el solo hecho que exista un curador o curadora responde ya a estructuras verticales” (Cortés, 2019).

En ambos comentarios, cuyos autores fueron preservados, es posible identificar un incómodo común en relación con el efecto autoritario de elegir obras para ser enmarcadas, como una gran curaduría institucional en el espacio público. Ese efecto de legitimación es percibido también en la difusión de la acción en la prensa, considerando que en 40\% del material analizado, los titulares de los artículos utilizan la palabra "galería" para definir el Museo de la Dignidad. Un dato interesante observado es que de entre estos $40 \%$ de vehículos que enfatizaron la dimensión institucional de la acción (conformación de una galería), la mayoría son vehículos del espectro de derecha. Los vehículos más identificados en el espectro de la izquierda analizado enfatizaron, en su mayoría, la idea de preservación (patrimonio) de la revolución.

\section{El Museo de la Dignidad y los regímenes del arte}

Volviendo al análisis de los comentarios críticos del Museo de la Dignidad, llama la atención, en el segundo ejemplo, la mención a la palabra "oro". El término elabora un aspecto fundamental de la acción: la elección de utilizar marcos dorados en las intervenciones. Si bien ese aspecto fue tangencialmente mencionado anteriormente, cuando interpretamos una intención de sacralización de la comunidad en el trabajo anterior, encontramos importante ahondar un poco más en este aspecto. En este punto, más que solamente identificar

ESCENA. Revista de las artes, 2021, Vol. 80, Núm. 2, pp. 253-296 ISSN 2215-4906 
Museo de la Dignidad: entre la polémica y la memoria.Una mirada

Dossier sobre las acciones artístico-políticas en el octubre chileno de 2019

el efecto "sacralizador" que estos marcos producen, creemos que es necesario también analizar cómo estos elementos producen la puesta en conflicto de distintos regímenes de visualidad del arte (Rancière, 2005).

Si hacemos un breve retorno al período de la UP y de la producción mural y gráfica de ese entonces, recordamos que en gran medida estas estuvieron conectadas a la difusión de las ideas de socialismo y de gobierno popular relacionadas con ese proyecto. De ese modo, es posible afirmar que el régimen que gobernaba la producción y hasta la fruición de estas imágenes se refiere a lo que Rancière denomina como Régimen ético de las imágenes: "en este régimen no hay arte hablando con propiedad, sino imágenes que juzgamos en función de su verdad intrínseca y de sus efectos sobre el modo de ser de los individuos y de la colectividad" (Rancière, 2005, p. 08).

Volviendo a Bowen (2008), vemos que parte del proyecto de la Unión Popular se trataba de crear una nueva cultura, basada en la visión crítica, donde el pueblo fuese educado para ver la "verdad" (o sea, para superar la falsa conciencia ideológica de la burguesía). De este modo, las imágenes producidas cumplían la función de revelar esa verdad para el pueblo y sacar la máscara a los procesos de mistificación producidos por la ideología burguesa, buscando producir efectos emancipatorios en los individuos y en la comunidad a la que se dirigía. De igual manera, gran parte del arte gráfico y callejero producido en las décadas posteriores (especialmente entre fines de los años 1970 y mediados de la década de 1980), se acercaba al régimen ético de las imágenes en su acción de resistencia a la dictadura y de colaboración en la reconexión de vínculos comunitarios perdidos tras el golpe militar.

Imagen 19. Javier Barraza, Resistir (2019). llustración

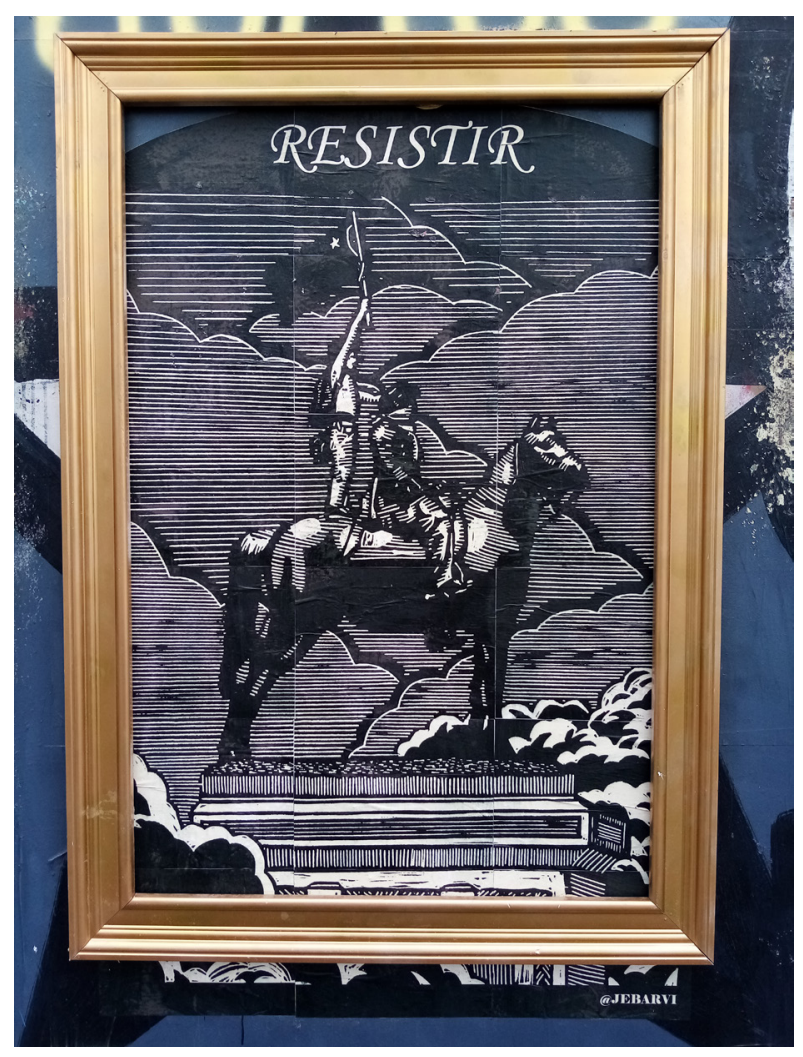

Fuente:Raíza Cavalcanti (2020).

ESCENA. Revista de las artes, 2021, Vol. 80, Núm. 2 (enero-junio), pp. 253-296 
Sin embargo, en las décadas posteriores, el arte callejero pasó a asumir otra dimensión más conectada al Régimen estético de las imágenes, dado que parte de esa producción se identificaba como artística en su acción y presencia en la calle. En este otro régimen de las artes, según Rancière:

la propiedad de ser considerado como arte no se refiere a una distinción entre los modos del hacer, sino a una distinción entre los modos de ser. Esto es lo que quiere decir estética: la propiedad de ser del arte en el régimen estético del arte ya no está dada por criterios de perfección técnica, sino por la asignación a una cierta forma de aprehensión mental (Rancière, 2005, p. 09).

Los cambios producidos por el arte moderno y por la emergencia de la estética en el régimen representativo de las artes -donde predomina la búsqueda por la apariencia verosímil y la jerarquía de los estilos-, abrió el camino para que la identificación de lo artístico no se refiriera solamente al cómo se hace y con qué materiales. Las transformaciones producidas en el campo artístico desde fines de la década de 1960 generaron profundas modificaciones en los modos de hacer y ver el arte, como la desmaterialización (arte conceptual) y el uso de distintos materiales y objetos en la producción artística. Estos procesos, junto con otros importantes cambios culturales producidos por la emergencia del discurso posmoderno y la valoración de culturas urbanas marginales, transformaron profundamente las clasificaciones, jerarquizaciones y modos de producción artísticos, lo cual posibilitó que los carteles, murales y graffitis callejeros se conviertan también en arte.

Estos cambios en los regímenes de las imágenes fueron producto de contestaciones y conflictos que tornaron el marco dorado, símbolo máximo de las "bellas artes" y de la excelencia técnica y de lo bello, como ícono de una visión cuestionable del arte al interior del régimen estético (que podríamos decir, es actualmente prevalente en el campo artístico). De este modo, no extraña que la presencia de marcos dorados en las calles, enmarcando pegatinas, murales y graffitis, pueda provocar reacciones críticas, considerando que este elemento está intrínsecamente conectado a un régimen de las imágenes que, como característica general, jerarquiza y verticaliza el arte a través de la noción orgánica de obra (Bürger, 1997).

Respecto del uso de los marcos dorados, Felipe Abufhele, director creativo y parte del colectivo, en una entrevista, explicó que:

Se estaba llenando de obras y empezamos a conceptualizar, a hacer una metáfora de cómo hacer un museo y se nos ocurrió llamarlo Museo de la Dignidad. Nos 
Museo de la Dignidad: entre la polémica y la memoria.Una mirada

Dossier sobre las acciones artístico-políticas en el octubre chileno de 2019

dimos cuenta que los muros del museo eran a cielo abierto y solo faltaba enmarcar las obras (Valles, 2019. Destaque de las autoras).

En la cita anterior, es posible notar que el integrante del grupo sitúa su representación del arte y de los museos al interior de lo que Rancière identifica como el régimen representativo de las artes. Tal manera de interpretar y definir, basada en categorías del arte que la acercan a la noción de bellas artes, lo lleva a definir las intervenciones en las calles como "obras" que conforman, en su conjunto, un museo. Para llegar a la condición de museo, por lo tanto, les falta un marco diferenciador y separador que las destaque de la calle. El museo, en esta representación, es un universo separador y "auratizador" del arte.

Sin embargo, al mirar más allá de las representaciones individuales sobre el marco y sus funciones, basadas en el régimen representativo del arte, que realizan los integrantes del grupo, se puede observar cómo la acción en sí misma promueve una interesante ruptura en los regímenes de organización del arte. En la imagen 14, se observa que el trabajo de Barraza está bastante identificado con el régimen ético de las imágenes, al enfatizar en la composición la comunicación de un mensaje que alude a un colectivo y una comunidad política: resistir. La presencia de dos personajes sobre el caballo empuñando la versión negra de la bandera de Chile y con los rostros cubiertos por pañuelos es un referente directo a los manifestantes, el cual, junto a la palabra "resistir", insta a que sigan en la manifestación. Los colores utilizados (mayormente oscuros) y la técnica que recuerda la serigrafía utilizada en los carteles y afiches del período de la resistencia gráfica de los años 1980 refuerzan la intencionalidad de producir un efecto político-ético.

Con todo, esta imagen y varias otras producidas en el marco del estallido social son vistas como artísticas tanto por quienes las producen como por quienes las miran (investigadores y ciudadanía que reconocen el carácter estético de estas piezas gráficas). Tomando en consideración que, en el marco del régimen estético, "el arte ya no está dada por criterios de perfección técnica, sino por la asignación a una cierta forma de aprehensión mental” (Rancière, 2005, p. 09), el estallido social produjo una explosión de imágenes que en su presencia en la calle y en su función de comunicar consignas y elaborar estéticamente el enojo social parecen circular constantemente entre lo ético y lo estético.

La acción de enmarcar estas imágenes producida por el Museo de la Dignidad inserta un tercer factor en ese juego intrincado, al incluirlas en el marco del régimen representativo del arte con el fin de "eternizarlas". De este modo, como acción que provoca el barajamiento 
de sentidos y modos ser y ver del arte, el Museo de la Dignidad en sí mismo es un acto artístico que provoca efectos desordenadores en un orden de sentidos determinado. Tal efecto produce reacciones en la esfera pública que van desde la crítica, hasta la adhesión.

\section{Museo de la Dignidad: preservar el arte callejero}

Los marcos dorados utilizados en las intervenciones aluden, además, a otra polémica (disenso) al interior del campo artístico: la compleja relación entre la calle y las instituciones como "espacios del arte" (Rancière, 2005) y la necesidad (legitimidad) o no del arte callejero en el acervo de los museos. El arte contemporáneo - la práctica artística ejemplar del régimen estético de las artes - ha puesto en evidencia, en muchos de sus procedimientos, los límites de los museos en conservar producciones artísticas que escapan a determinadas reglas materiales. De esta manera, muchos museos e instituciones culturales no han podido entregar respuestas satisfactorias a la pertinente cuestión evidenciada por el Museo de la Dignidad: ¿Cómo preservar la memoria de las intervenciones callejeras, cuya existencia es todavía criminalizada y negativizada por los poderes estatales y mediáticos en Chile? ${ }^{9}$

La manera en la que el discurso del gobierno actual insiste en utilizar nociones como suciedad y criminalidad al referirse a las intervenciones callejeras es un dato fundamental para comprender la dimensión agonística del arte callejero en Chile ${ }^{10}$. El borramiento como estrategia política para callar las voces y expresiones que se apoderan de los muros de la ciudad todavía es un recurso utilizado por el Estado para impedir o invisibilizar (a veces ambas) la emergencia del disenso en la esfera pública. Ejemplo de ello fue el borramiento masivo de los rayados, afiches, carteles y murales producidos durante el estallido, llevado a cabo en febrero de 2020, hecho que generó una ola de protestas y de acciones colectivas de restitución de las imágenes eliminadas (El Mostrador Cultura, 2020).

9 El investigador Rubens Dittus (2019) presenta un importante dato sobre este aspecto:

${ }^{10}$ Desde el año 2018 el gobierno de Sebastián Piñera hizo un llamado a castigar a quienes rayaran las calles con multas y reclusión. Fue el mismo ex Ministro de Cultura y actual diputado Luciano Cruz-Coke que presentó el proyecto al Congreso arguyendo que quienes rayan no son considerados como artistas, sino más bien, quienes hacen esto lo hacen con una intención de rebeldía ante el sistema que daña la propiedad pública o privada y los catalogó como "contaminación visual" (Fajardo, 2018, citado en Dittus, 2019, p.201). 
Museo de la Dignidad: entre la polémica y la memoria.Una mirada

Dossier sobre las acciones artístico-políticas en el octubre chileno de 2019

De esta forma, la importancia de la preservación del arte callejero que, en su esencia, es efímero cobra aquí un importante aspecto político de lucha por mantener el disenso en evidencia. En este punto, más que los marcos dorados en el espacio público, la acción de creación de páginas en las redes sociales por el Museo de la Dignidad es la que, en definitiva, termina cumpliendo el objetivo de "preservar" las intervenciones elegidas declarado por el grupo (Salinas, 2019). Al generar un repositorio digital de los trabajos, el Museo de la Dignidad participa de lo que algunos investigadores definen como proceso de pérdida de la efimeridad de las intervenciones callejeras producidas por la internet. Para el investigador Rubens Dittus:

En ese sentido, es interesante el desplazamiento del grafiti como mensaje, ya que está perdiendo unas de sus características más importantes: su esencia efímera. Internet y los dispositivos móviles hoy operan como los nuevos "muros" donde este grabado contemporáneo ya no se pierde (Márquez, 2017), queda guardado en la posteridad entremedio de estas redes de comunicaciones interconectadas globalmente (Dittus, 2019, p. 203).

El uso de las redes sociales y la reproducción digital de la memoria de las intervenciones callejeras ahora es un tema de crucial importancia, dado que la contingencia provocada por la pandemia del COVID 19 generó como consecuencia la reducción de la esfera pública (y de la ocupación de las calles) a su dimensión digital (virtual). Sin la posibilidad de ocupar físicamente los muros y las veredas, las protestas callejeras en Chile viven actualmente un período de paralización. El vacío de las calles fue ocupado por las instituciones municipales que salieron a realizar nuevamente el trabajo de "blanqueamiento" de la ciudad, volviendo a borrar las imágenes, carteles y rayados.

Junto a esto, es importante mencionar que el actual momento ha provocado una profunda crisis en el sector cultural por el mundo, llevando a muchos museos e instituciones culturales a replantear sus roles y sus dispositivos de exhibición y difusión de colecciones. De este modo, es irónico darse cuenta que, en su intento de sacralizar para preservar las piezas gráficas en la calle usando los marcos dorados como dispositivo de separación, sean las redes sociales del Museo de la Dignidad las que han producido esa permanencia y recuperación patrimonial de las intervenciones artísticas callejeras del octubre de 2019.

En resumen, el acto de selección realizado por el Museo de la Dignidad, que evidencia en la esfera pública los dispositivos de legitimación y preservación de las instituciones culturales, está acompañado de su crisis, ya que la propia acción sufrió las consecuencias de la reducción del espacio público por la pandemia del nuevo coronavirus. De esta manera, 
la acción participa en las discusiones sobre la virtualización de la cultura, nuevos medios de producción y circulación, pues ahora se replica indefinidamente en el medio virtual.

\section{Consideraciones finales}

Este artículo es un esfuerzo inicial por producir reflexiones sobre la acción Museo de la Dignidad en la esfera pública (virtual y física) chilena. De esta manera, el presente texto no agota las innúmeras cuestiones que la acción y los materiales que genera son capaces de suscitar. Por ejemplo, la polémica sobre las relaciones entre el espacio institucional y su "exterior", la cual de por sí genera series de discusiones importantes, necesita ser más ahondada. Es importante seguir inquiriendo al trabajo cuestiones tales como: ¿De qué manera las fronteras institucionales del arte, que no conocen necesariamente muros físicos, son tensionadas, trasladadas o reforzadas por la acción?

También, nos interesa seguir profundizando aspectos de la acción relacionados con el campo artístico chileno y continuar con la reflexión sobre los motivos que impulsan la ocupación masiva de los muros de la ciudad por artistas de distintas identificaciones estéticas (fotógrafos, artistas visuales, artistas gráficos y street artists), sea organizados en colectivos o de manera individual. Además, la acción Museo de la Dignidad dejó en evidencia los límites del campo artístico chileno en términos de inserción, circulación, legitimación y mercado del arte. Al observar el discurso elaborado por el grupo creador del Museo de la Dignidad para justificar la realización de la acción, vemos que este se basa en la percepción de los integrantes de la presencia de "obras" de artistas "emergentes" y "conocidos" en los muros de la ciudad que necesitaban ser preservados.

Por tanto, es posible relacionar este aspecto con la necesidad de generar espacios de visibilidad para trabajos y artistas que, de manera casi general, trabajan desde la informalidad y autónomamente en relación con galerías e instituciones en Chile. Asimismo, es un dato interesante de observar la manera cómo el grupo relaciona los trabajos enmarcados con sus autores, etiquetando sus cuentas individuales en los posts para facilitar la identificación de los perfiles por los usuarios de la página. La visibilidad entregada por la acción a algunos trabajos y artistas lleva a que tengan sus nombres en circulación y alcancen nuevos públicos (y probables consumidores). De este modo, queda por analizar en qué medida esa acción en el espacio público puede funcionar como un nuevo mecanismo de legitimación y visibilidad para el arte callejero o si, en otro sentido, produce la apertura para una reflexión sobre los límites de las instituciones y el mercado artístico chileno, al exponer la brecha de integración de un gran número de artistas.

ESCENA. Revista de las artes, 2021, Vol. 80, Núm. 2 (enero-junio), pp.253-296 
Museo de la Dignidad: entre la polémica y la memoria.Una mirada

Dossier sobre las acciones artístico-políticas en el octubre chileno de 2019

Finalmente, en el actual contexto de emergencia sanitaria, donde la presencia en las calles quedó interdicta, cobra importancia el registro virtual de la acción. En medio a la actual reflexión sobre la necesidad de generar estrategias de supervivencia en el espacio digital provocadas por la pandemia, el Museo de la Dignidad terminó por adelantarse a la contingencia, produciendo una plataforma de preservación de la memoria visual de la revuelta social en Chile de los últimos meses. Este es un aspecto más que merece ser profundizado a la luz de las discusiones sobre la digitalización de las colecciones institucionales, la producción de repositorios online para el acceso público a estas o la creación de muestras virtuales.

Estas son cuestiones que aún nos convocan a seguir profundizando en el análisis del Museo de la Dignidad, cuya performance sigue operando a pesar de "finalizada" la acción. Su relevancia no termina de hacerse presente, dada la interesante mezcla de medios de acción articulados por el grupo y los efectos que produce.

\section{Referencias:}

Ardèvol, E.; Bertrán, M.; Callén, B. \& Pérez, C. (2003). Etnografía virtualizada: la observación participante y la entrevista semiestructurada en línea. Athenea Digital. Revista de Pensamiento e Investigación Social, 3, 72-92.

Asamblea por el Pacto Social (2019). Declaración Asamblea por el Pacto Social. Recuperado de https://www.porelpactosocial.cl/

Becerra, A. (15 de diciembre 2019). Museo de la Dignidad: el proyecto que busca conservar las obras que dejó la movilización. Diario UChile. Recuperado de https://radio.uchile. cl/2019/12/15/museo-de-la-dignidad-el-proyecto-que-busca-conservar-las-obrasque-dejo-la-movilizacion/

Biblioteca Nacional de Chile (s.f.a). Editora Nacional Quimantú. Recuperado de http://www. memoriachilena.gob.cl/602/w3-article-3362.html.

Biblioteca Nacional de Chile (s.f.b). Nuevo Cine chileno. Recuperado de http://www.memoriachilena.gob.cl/602/w3-article-92826.html

Bowen, M. (2008). El proyecto sociocultural de la izquierda chilena durante la Unidad Popular. Crítica, verdad e inmunología política. Nuevo Mundo. Mundos Nuevos. doi: 10.4000/ nuevomundo.13732

ESCENA. Revista de las artes, 2021, Vol. 80, Núm. 2 (enero-junio), pp. 253-296 
Brodsky, V. (28 de noviembre de 2019). Quien determina lo que es digno de ser enmarcado en "oro"? El lenguaje de la calle, a mi modo de ver, debe estar desprovisto de las lógicas de la selección estética bajo criterios de belleza u otros. Me parece interesante cuestionarlos. Recuperado de https://m.facebook.com/story/graphql_permalink/?graphql_id=UzpfSTEwMDAwMjY2NTM4NzMxMzoyNDI5MzUwMDMzODMwNDg2

Bürger, P. (1997). Teoría de la Vanguardia. Barcelona: Península.

Cortés, G. (28 de noviembre de 2019). "El solo hecho que exista un curador o curadora responsable responde ya a estructuras verticales". Recuperado de https://m. facebook.com/story/graphql_permalink/?graphql_id=UzpfSTEwMDAwMjY2NTM4NzMxMzoyNDI5MzUwMDMzODMwNDg2

Cristi, N. \& Manzi, J. (2017). Construcción de una trinchera gráfica: la experiencia de la Agrupación de Plásticos Jóvenes (APJ) y el Tallersol durante la dictadura en Chile. Revista Chilena de Diseño, 2(3), 1-14. doi: 10.5354/0719-837x.2017.47690

Dalmás, C. (2007). As brigadas muralistas da experiência chilena: propaganda política e imaginário revolucionário. Revista História, São Paulo, 26 (2), 226-256. doi: 10.1590/ S0101-90742007000200012

Dittus, R. (2019). Las paredes hablan en Chile: crisis social, grafiti y arte callejero. Revista Chilena de Semiótica, 12, 198-214. Recuperado de https://www.revistachilenasemiotica.cl/numero-12/

El Mostrador Cultura. (19 de febrero 2020). Callar la calle: Centro GAM y Arte Alameda condenan el "borrado" de sus fachadas que registraban la historia del estallido social. El Mostrador. Recuperado de https://www.elmostrador.cl/cultura/2020/02/19/callar-la-calle-centro-gam-y-arte-alameda-condenan-el-borrado-de-sus-fachadas-que-registraban-la-historia-del-estallido-social/

Espinoza, E.C. (2004). Cartel Chileno 1963-1973. Santiago: Ediciones B Chile.

Fairclough, N. (2001). Discurso e Mudança Social. Brasilia: UnB.

Jara, I. (2019). Impresiones visuales de la primavera chilena 2019. Recuperado de: https://aauchile.com/2020/10/14/impresiones-visuales-de-la-primavera-chilena-2019/

La Cuadra, F. (2013). Apontamentos sobre o conflito e os movimentos sociais no Chile. 
Museo de la Dignidad: entre la polémica y la memoria.Una mirada

Dossier sobre las acciones artístico-políticas en el octubre chileno de 2019

DILEMAS: Revista de Estudos de Conflitos e Controle Social, 6(4), 581-602.

Lincopi, C. (2019). Plurinacionalidad y autodeterminación de los pueblos. Palabra Pública, 16, 60-61. Recuperado de: http://www.libros.uchile.cl/files/revistas/DIRCOM/ PalabraPublica/16-nov-dic2019/index.html

Molina, I., Facuse, M. \& Yáñez, I. (2019). Quimantú: Prácticas, Política y Memoria. Santiago: Grafito.

Mônckeberk, M. (2019). La raíz del estallido y el fracaso del modelo neoliberal. Especial Palabra Pública,16, 73-75. Recuperado de: http://www.libros.uchile.cl/files/revistas/DIRCOM/PalabraPublica/16-nov-dic2019/index.html

Mouffe, C. (2014). Agonística: pensar el mundo políticamente. Buenos Aires: Fondo de Cultura Económica.

Nash, C. (2019). DD.HH. en Chile: No son los 10 días del Estado de excepción, son los 30 años de degradación de un ideal común. Palabra Pública, 16, 82-83. Recuperado de: http://www.libros.uchile.cl/files/revistas/DIRCOM/PalabraPublica/16-nov-dic2019/index.html

Rancière, J. (2005). Sobre políticas estéticas. Barcelona: Museo de Arte Contemporáneo y Universidad Autónoma de Barcelona.

Rancière, J. (2009). A Partilha do Sensível. São Paulo: Editora 34.

Rodríguez-Plaza, P. (2001). La Pintura Callejera Chilena: manufactura estética y territorialidad. Revista Aisthesis, 34, 171-184.

Rodríguez-Plaza, P. (2003). El Chile de la Unidad Popular: una mirada de la visualidad urbana de aquel tiempo. Revista Aisthesis, 36, 125-137.

Salinas, D. (2019). Arte y Dignidad en la era digital. Revista de Gestión Cultural, 14, 12-15.

The Clinic (2019). Museo de la Dignidad: Una muestra histórica inspirada en la Revolución. Recuperado de: https://www.theclinic.cl/2019/12/13/museo-de-la-dignidad-una-muestra-historica-inspirada-en-la-revolucion/ 
Raíza Ribeiro Cavalcanti

Teresa Maria Barbosa de Oliveira

Torres, D. (2019). Museo de la Dignidad, la galería de arte a cielo abierto que está en plena Alameda. La Tercera. Recuperado de https://finde.latercera.com/cultura-pop/museo-de-la-dignidad-santiago/

Valles, P. (2019). Museo de la Dignidad: una galería callejera en medio de la revolución. La Tercera. Disponible en: https://www.latercera.com/culto/2019/12/10/museo-la-dignidad/ 
Museo de la Dignidad: entre la polémica y la memoria.Una mirada

Dossier sobre las acciones artístico-políticas en el octubre chileno de 2019 